\title{
3-D modelling of a fossil tufa outcrop. The example of La Peña del Manto (Soria, Spain)
}

\author{
Pedro Huerta ${ }^{\mathrm{a}, *}$, Ildefonso Armenteros ${ }^{\mathrm{b}}$, Oscar Merino Tomé ${ }^{\mathrm{c}}$, Pablo Rodríguez Gonzálvez ${ }^{\mathrm{d}}$, Pablo G. Silva ${ }^{\mathrm{a}}$, \\ Diego González-Aguilera ${ }^{\mathrm{d}}$, Pedro Carrasco-García ${ }^{\mathrm{d}}$ \\ a Dpto. de Geología, Escuela Politécnica Superior de Ávila, Universidad de Salamanca, Avd/ Hornos Caleros no. 50, 05003 Ávila, Spain \\ b Dpto. de Geología, Fac. de Ciencias, Universidad de Salamanca, Pza. de la Merced s/n, 37008 Salamanca, Spain \\ ' Dpto. de Geología, Universidad de Oviedo, c) Jesús Arias de Velasco, s/n, 33005 Oviedo, Spain \\ d Dpto. de Ingeniería Cartográfica y del Terreno, Escuela Politécnica Superior de Ávila, Universidad de Salamanca, Avd/ Hornos Caleros no. 50, 05003 Ávila, Spain
}

\section{A R T I C L E I N F O}

\section{Article history:}

Received 27 October 2015

Received in revised form 22 December 2015

Accepted 23 December 2015

Available online 31 December 2015

Editor: Dr. B. Jones

\section{Keywords:}

Tufa

Pleistocene

Spain

Non-marine

Fluvial

Cascade

\begin{abstract}
A B S T R A C T
Classical studies of tufas lack quantitative outcrop descriptions and facies models, and normally do not integrate data from subsurface in the stratigraphic and evolutive analysis. This paper describes the methodology followed to construct one of the first digital outcrop models of fossil tufas. This model incorporates 3-D lines and surfaces obtained from a terrestrial laser scanner, electric resistivity tomography (ERT) profiles, and stratigraphic and sedimentologic data from 18 measured sections. This study has identified seven sedimentary units (from SU-1 to SU-7) which are composed of tufa carbonates (SU-1; $3 ; 5 ; 6)$ and clastics (SU-2; 4; 7). Facies identified occur in different proportions: phytoherm limestones of bryophytes represent $43 \%$ of tufa volume, bioclastic limestones $20 \%$, phytoherm limestones of stems $12 \%$, oncolitic limestones $8 \%$, and clastics $15 \%$. Three main architectural elements have been identified: 1) Steeply dipping strata dominated by phytoherm limestones of bryophytes; 2) gently dipping strata dominated by phytoherm limestones of stems; and 3 ) horizontal strata dominated by bioclastic and oncoid limestones. The alternation of tufa growth and clastic input stages is interpreted as the result of climatic changes during Mid-Late Pleistocene.
\end{abstract}

(c) 2015 Elsevier B.V. All rights reserved.

\section{Introduction}

Tufas have been widely studied from different points of view, hydrological, biological, geomorphological, sedimentological and mainly climatic (Andrews et al., 2000; Peña et al., 2000; Matsuoka et al., 2001; Garnett et al., 2004). A great number of papers have described the sedimentary model of tufas and their evolution (Pedley, 1990; Ford and Pedley, 1996; Pedley, 2009; Vázquez-Urbez et al., 2012; Arenas et al., 2014), but in many cases there is a lack of subsurface information. Pedley et al. (2000) studied and modelled the 3-D structure of a barrage tufa in the Lathkill Valley (U.K.) with ground-penetrating radar (GPR). This, the first paper to study tufa deposits with GPR, constructed 2-D isobath and isopach maps for the main truncation surfaces. The importance of this kind of study is their contribution of a subsurface view of tufas and characterization of potential analog for water-constructed landforms on Mars (Pellicer et al., 2014). The integration of sedimentary logs, detailed facies mapping, electrical resistivity tomography (ERT),

\footnotetext{
* Corresponding author.

E-mail address: phuerta@usal.es (P. Huerta).
}

GPS, and terrestrial laser scanner data using new software developed recently for the oil industry improves correlations between outcrops (Jennette and Bellian, 2003; Bellian et al., 2005; Verwer et al., 2007; Kenter et al., 2008; Verwer et al., 2009a; Verwer et al., 2009b; Fabuel-Pérez et al., 2010; Merino-Tomé et al., 2012). Software such as PETREL helps develop facies modelling based on deterministic and stochastic methods from log and facies maps, thus providing the opportunity to extract quantitative information relevant to the understanding of the spatial distribution of sedimentary facies and their physical properties. Similar integrated studies have been developed recently to characterize carbonate and siliciclastic marine and nonmarine sedimentary systems (Adams et al., 2004; Falivene et al., 2007; Verwer et al., 2009a; Verwer et al., 2009b; Fabuel-Pérez et al., 2010; Cabello et al., 2011; Amour et al., 2012; Merino-Tomé et al., 2012; Amour et al., 2013).

The objective of this paper is to put together data from subsurface, sedimentological analysis and geomorphology acquired with classical and new techniques (i.e. terrestrial laser scanner) from an excellent outcrop of a recent tufa system to create a 3-D digital outcrop model (DOM) wherein the main characteristics of the tufa can be described, measured and quantified. 


\section{Geological and geomorphological setting}

The Peña del Manto is a Quaternary fossil tufa developed on the left margin of the Henar valley, close to Deza village (Soria, Spain) (Fig. 1). Its deposits unconformably overlie Paleogene conglomerates, sandstones and mudstones that form the infill of the Cenozoic Almazán basin, which is dissected by the modern fluvial drainage network (Huerta, 2007; Huerta et al., 2010; Huerta et al., 2011; Valero et al., 2015).

This tufa and older, related Oligocene tufas forming part of the Almazán basin infill occur along the Aragonian branch of the Iberian
Chain, which forms the NE margin and substrate of the Cenozoic Almazán basin (Fig. 1). In the Deza area, Paleozoic metamorphic rocks and Mesozoic sandstones and limestones are exposed and affected by several northward verging thrusts.

Nowadays, active tufa deposits form in relation with springs located at the contact between Upper Cretaceous limestones and Paleogene clastic-carbonate succession of the Almazán basin (Huerta, 2007). In these springs, water temperature and salinity increase towards the southeast along the Aragonian Range (Yélamos and Sanz Pérez, 1998). Bicarbonate content of present-day waters exceeds $300 \mathrm{mg} / \mathrm{l}$ in Deza

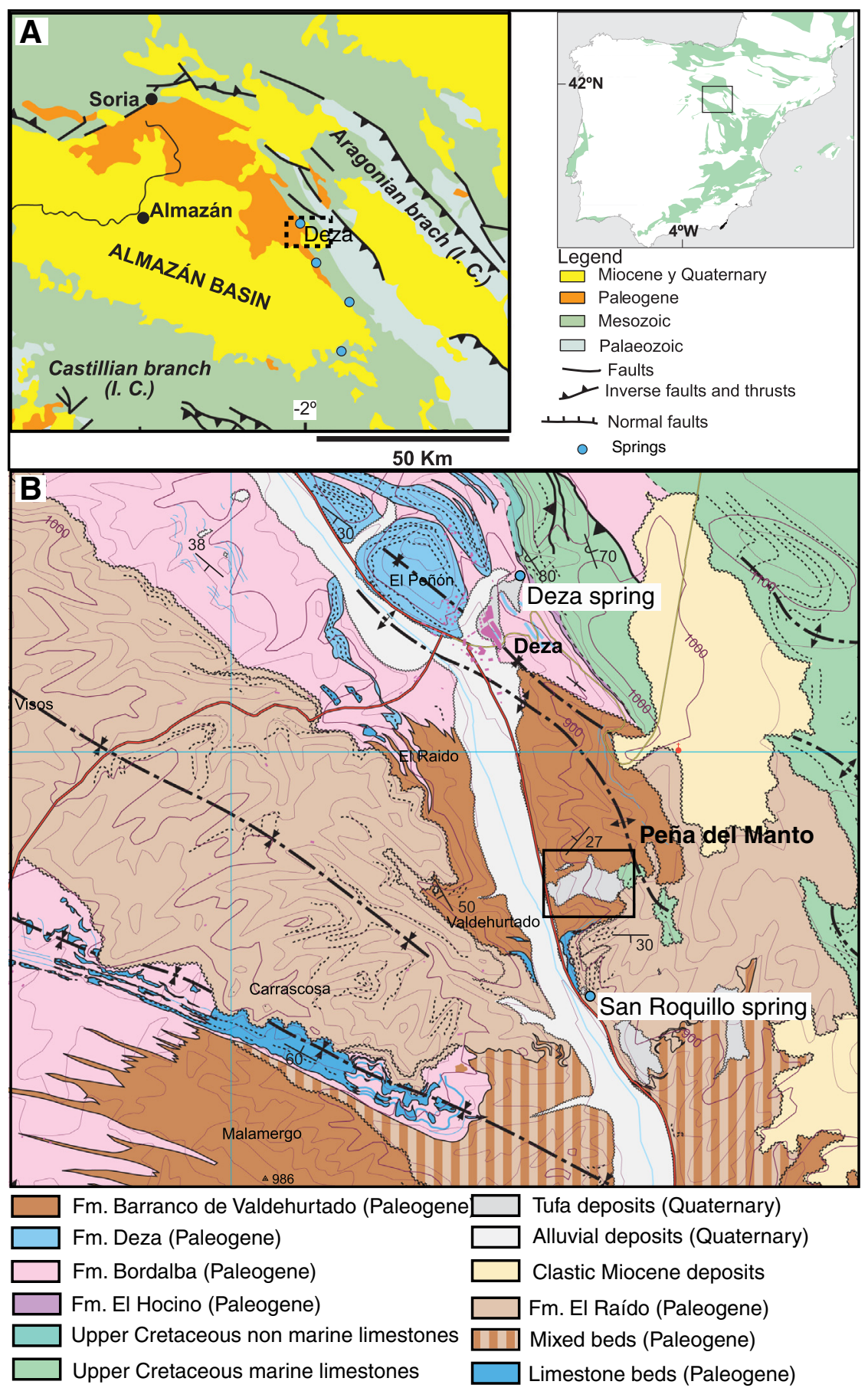

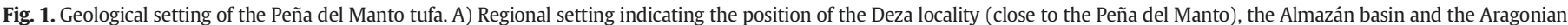

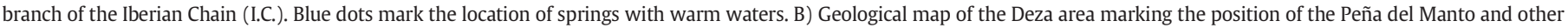
Quaternary tufa deposits. (For interpretation of the reference to colour in this figure legend, the reader is referred to the web version of this article.) Huerta (2007) 
and San Roquillo springs (Fig. 1), while $\mathrm{Ca}^{2+}$ and $\mathrm{Mg}^{2+}$ are around 100 and $30 \mathrm{mg} / \mathrm{l}$, respectively.

\section{Methods}

\subsection{Field data acquisition, sedimentologic analyses and geological mapping}

A digital elevation model (DEM) with 2- and 5-cm resolution covering the entire outcrop was acquired with a terrestrial Trimble GX laser scanner. At the same time photopanels were taken with a calibrated Nikon D80 reflex digital camera that were later geo-referenced, overlapping the DEM in order to assign RGB to the laser scan point cloud and to obtain accurate information of stratal patterns.

Eighteen stratigraphic sections were measured and described following the same protocol (Fig. 2). The position of every strata boundary in stratigraphic sections was located accurately in the georeferenced laser scan point cloud (Fig. 3). Favourable outcrop characteristics allowed lateral tracing of continuous stratal surfaces and correlation of stratigraphic sections through bedding planes and the accurate reconstruction of depositional architecture.

A facies catalogue was created based on the code proposed by Arenas-Abad et al. (2010), also including new facies present in our case (Table 1). Two 1:5000-scale geomorphological and stratigraphic maps were elaborated using $0.5 \mathrm{~m}$ pixel size orthophoto and stereoscopic aerial photos from the regional mapping service (Instituto Tecnológico Agrario de Castilla y León, ITACYL). The stratigraphic map accurately represents the spatial distribution of discrete sedimentary units recognized in the tufa.
A geophysical survey of electric resistivity tomography (ERT) was done in order to reconstruct the tufa geometry in the subsurface, up to a maximum depth of nearly $40 \mathrm{~m}$. Two perpendicular ERT profiles, registering the apparent terrain resistivities along the profile at different depths with a $3 \times 3 \mathrm{~m}$ resolution, were obtained with a multi-channel resistimeter (IRIS Sycal Pro ${ }^{\circ}$ ) spacing the electrodes every $3 \mathrm{~m}$ with pole-dipole and Schlumberger arrangement. Profile 1 has a length of $438 \mathrm{~m}$ and W-E. Profile 2 is N-S directed of a length of $141 \mathrm{~m}$ (Fig. 2). Apparent resistivities were transformed into pseudo cross-sections to represent the terrain electric resistivity distribution, with RES2Dinv ${ }^{\circledR}$ software.

\subsection{Digital outcrop model (DOM)}

In this study a 3-D digital outcrop model (DOM) of the Peña del Manto tufa was constructed using PETREL modelling software (Schlumberger Ldt.), following the workflow described by Bellian et al. (2005) and Verwer et al. (2007).

The DOM integrates: 1) a detailed digital elevation model (DEM); 2) photo panels covering all outcrop exposures; 3) 18 stratigraphic sections imported as pseudo-wells indicating the $\mathrm{X}, \mathrm{Y}$ and $\mathrm{Z}$ coordinates of every strata boundary along with a numerical code corresponding to the assigned facies; 4) two electric resistivity tomography (ERT) profiles; 5) 1:5.000-scale geomorphological and stratigraphic maps; and 6) local observations concerning lithofacies.

The outcrop model is formed by three-dimensional modelled (gridded) stratigraphic surfaces conditioned to outcrop data, stratigraphic sections imported as pseudo-wells and to interpretation of

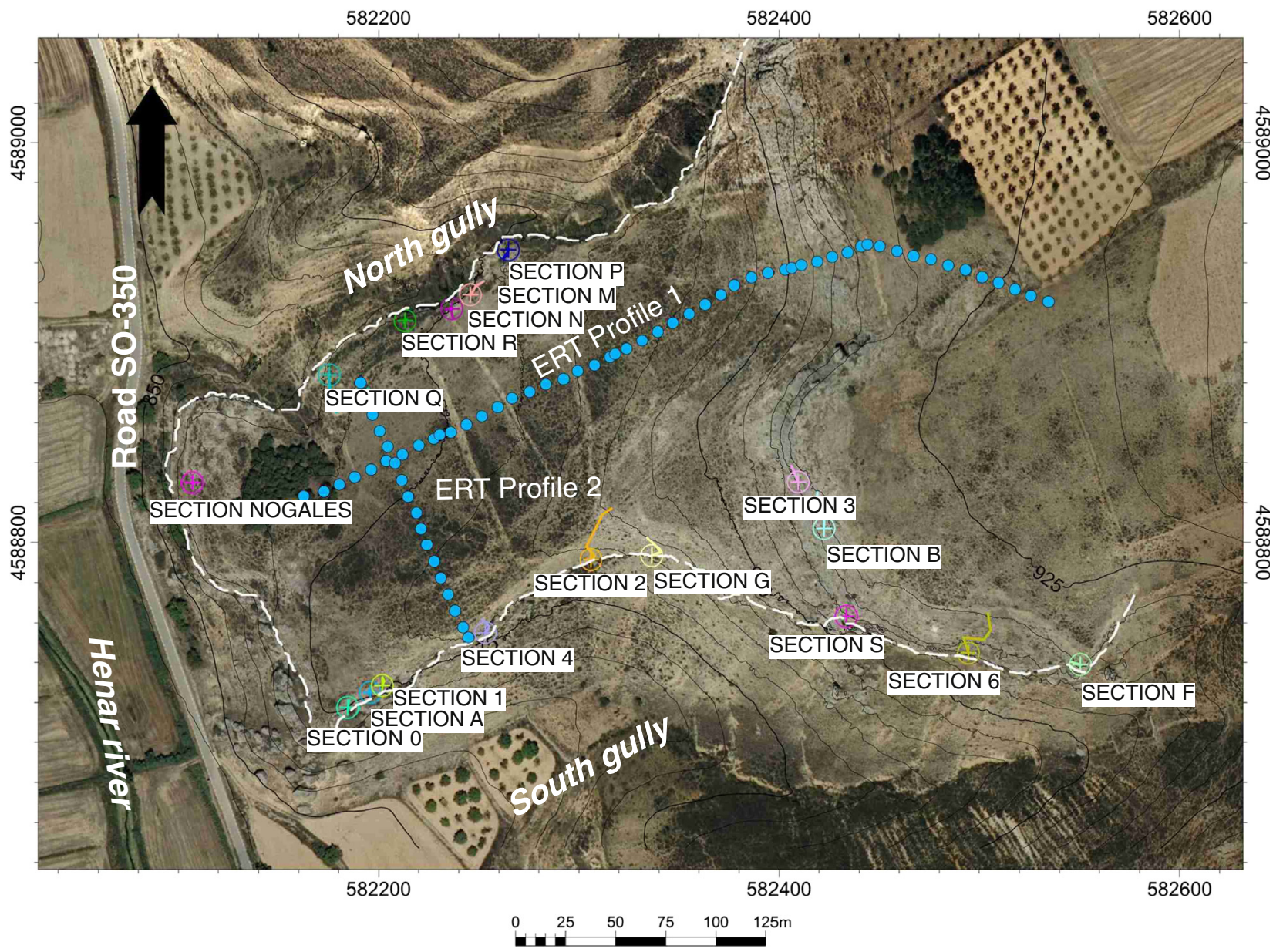

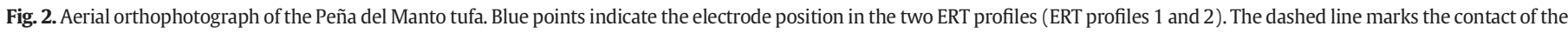

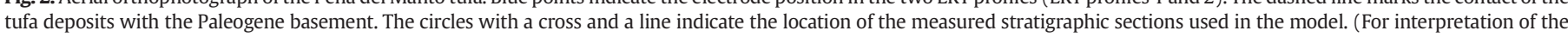
reference to colour in this figure legend, the reader is referred to the web version of this article.) 


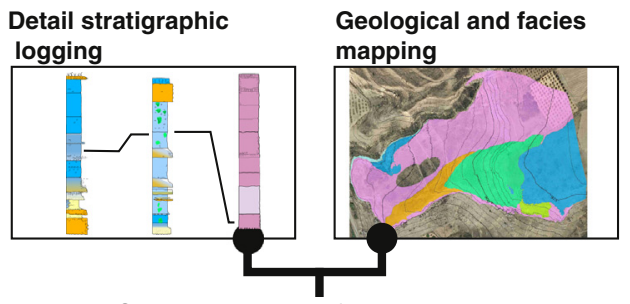

Stratigraphy and the facies observed are represented as georeferenced logs and maps.

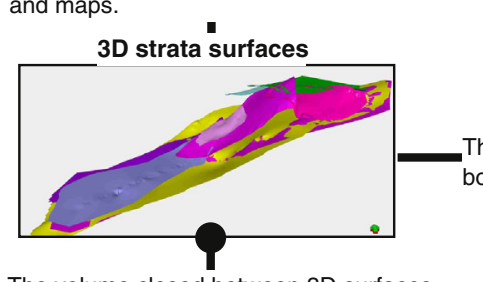

The volume closed between 3D surfaces is used to create the $3 D$ structural model constituted by cells.

3D structural outcrop model

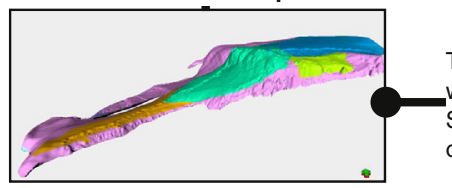

Electric resistivity tomography

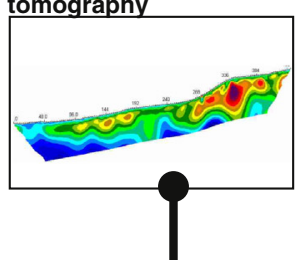

It is used to correlate buried units, distinguish between clastic and carbonate units, to identify caves, and to construct 3D surfaces.

The 3D lines corresponding to the same strata boundary are used to construct 3D surfaces.
Interpreted photopanels Ground based laser

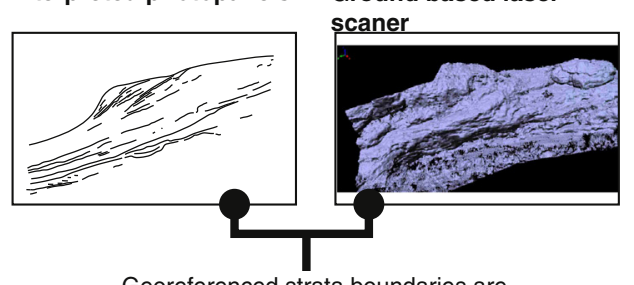

Georeferenced strata boundaries are

drawn from the laser point cloud

.

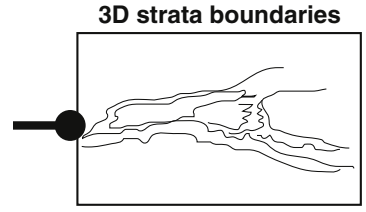

Fig. 3. Scheme of the workflow used to create the 3D digital outcrop model of the Peña del Manto tufa, from data acquisition.

ETR profiles. These stratigraphic surfaces bounding the sedimentary units recognized in the tufa system are designed to reflect observed stratal geometries. In a later stage, a three-dimensional grid was developed with a $30 \mathrm{~cm} \times 30 \mathrm{~cm} \mathrm{X}$ and Y cell size (Fig. 3).

\subsection{Facies modelling}

In order to simplify facies modelling, facies were grouped in 10 categories (see Table 2). The skeleton of the facies model is formed by upscaled cells of the modelling grid that take a facies value from imported pseudo-wells, local observations, and facies distribution maps. Stochastic and deterministic facies modelling algorithms included in PETREL ${ }^{\circledR}$ (Schlumberger Ldt.) were used to simulate the 3-D facies distribution across the tufa. Similar facies modelling processes have been used in alluvial and fan delta reservoir modelling (Martinius and Naess, 2005; Falivene et al., 2007; Cabello et al., 2011).

\section{Results}

\subsection{Stratigraphy}

The Peña del Manto tufa exposure preserves the original geometry of the tufa system. Its morphology in plan view is similar to a $540 \mathrm{~m}$ long and $160 \mathrm{~m}$ wide rectangle elongated in SW-NE direction (Figs. 2, 4). The eastern top of the tufa is $930 \mathrm{~m}$ above sea level, while the western termination is at nearly $850 \mathrm{~m}$, representing $70 \mathrm{~m}$ of difference in altitude (Fig. 2). Two sub-horizontal levels made up of $3^{\circ}-12^{\circ}$ dipping strata at different heights (920-930 $\mathrm{m}$ above sea level, and 870-890 m above sea level, respectively) can be recognized, connected by a steep slope area dipping around $60^{\circ}$ in the eastern half of the tufa, mostly formed by steeply-dipping strata (Figs. 2, 4). The westward termination of the tufa in the vicinity of the Río Henares fluvial plain corresponds to a 15-m high cliff (Fig. 2). Recent fluvial incision has eroded the north and south gullies of the Peña del Manto, exposing two E-W oriented and continuous outcrops showing the internal architecture of the tufa system, and downstream geometry and facies transition (Figs. 4, 5).
Strata forming the Peña del Manto tufa can be subdivided in 7 sedimentary units bounded by erosional surfaces that can be traced in the entire tufa (Figs. 4, 5). These sedimentary units (SU) have been named from 1 to 7, from older to younger. SU-2, 4 and 7 are composed of clastic deposits, mainly conglomerates with quartzite clasts, sandstones and mudstones, while SU-1, 3, 5 and 6 are composed mainly of carbonate tufa deposits (Fig. 6).

\subsubsection{The north gully outcrop}

The north gully was excavated following the stratigraphic contact between tufa carbonates and the Paleogene substrate (Fig. 2). Tufa deposits mainly crop out at the left side of the gully, commonly forming vertical cliffs about $3 \mathrm{~m}$ high with excellent exposure (Figs. 4, 5).

In the eastern part of the gully (Fig. 2) tufa is dissected and exposed at both sides of steeply dipping strata of SU-3. Towards the western part of this gully, gentle dipping strata belonging to SU-1, 2 and 3 extend until the connection with the Henar valley (Fig. 4). Nevertheless, an area with steep strata dips is observed in the middle part of the gully, around section M (Figs. 2, 4, 5). SU-2, mainly made up of clastic deposits, crops out at the western half of the gully and wedges laterally towards the Henar valley.

Frontal cliffs of Peña del Manto outcrops are parallel to the Henar river valley (Fig. 2) and in its northern half are made up of SU-1 and 3 strata and, in the southern half, of SU 3 strata (Fig. 4).

\subsubsection{The south gully outcrop}

In the south gully exposure deposits of SU 3, SU 5 and SU-6 form steeply dipping strata complexes $\left(20^{\circ}-85^{\circ}\right)$ in the eastern part of the gully that laterally pass to gentle dipping to sub-horizontal strata $\left(1^{\circ}-\right.$ $11^{\circ}$ ) at the western part (Fig. 2). In the connection between south gully and the Henar valley, steeply dipping strata occur, although they are almost completely eroded (Fig. 2).

Three areas with steeply dipping strata are observed: 1) located in the upstream part of the gully (from Section F to Section 6) within SU3; 2) located between Section S to Section 2, comprising strata of SU 3 
Table 1

Tufa facies, their main characteristics and sedimentary environment interpretation.

\begin{tabular}{|c|c|c|c|c|c|}
\hline $\begin{array}{l}\text { Carbonate } \\
\text { facies }\end{array}$ & $\begin{array}{l}\text { Texture and } \\
\text { microstructure }\end{array}$ & Geometry & Sedimentary/biological structures & Sedimentary environmental context & \\
\hline Lbr & $\begin{array}{l}\text { Phytoherm } \\
\text { limestones of } \\
\text { bryophytes }\end{array}$ & $\begin{array}{l}\text { Boundstone of mosses coated with } \\
\text { calcite. }\end{array}$ & $\begin{array}{l}\text { Tabular and wedge-shaped strata } \\
\text { stacked vertically and laterally. } \\
\text { Thickness from } 2 \text { to } 10 \mathrm{~cm} \text { thick } \\
\text { every bed. In most of the cases the } \\
\text { beds dips from } 5^{\circ}-60^{\circ} \text {. }\end{array}$ & $\begin{array}{l}\text { Bryophytes grow perpendicular to } \\
\text { the bed (Fig. 7A). Insect traces and } \\
\text { mould of trees are common. } \\
\text { Cyanobacteria, gastropods and } \\
\text { occasionally ostracods are present. }\end{array}$ & Cascades and jumps. \\
\hline Lbra & $\begin{array}{l}\text { Phytoherm } \\
\text { limestones of } \\
\text { branched-structure } \\
\text { bryophytes }\end{array}$ & $\begin{array}{l}\text { Boundstone bryophytes with } \\
\text { branched structure coated with } \\
\text { calcite. }\end{array}$ & $\begin{array}{l}\text { Globular or bush-like geometry, } \\
15-30 \mathrm{~cm} \text { in height. }\end{array}$ & $\begin{array}{l}\text { Branching structures growing } \\
\text { vertically. Gastropods and } \\
\text { occasionally ostracods are present. }\end{array}$ & Cascades and jumps. \\
\hline Lch & $\begin{array}{l}\text { Phytoherm } \\
\text { limestones of } \\
\text { charophytes }\end{array}$ & $\begin{array}{l}\text { Boundstone of charophytes coated } \\
\text { with calcite forming palisades. }\end{array}$ & $\begin{array}{l}\text { Globular or bush like geometry } \\
\text { about } 10 \text { to } 15 \mathrm{~cm} \text { in height and } \\
\text { width. }\end{array}$ & Gastropod shells are common. & $\begin{array}{l}\text { Standing waters in streams } \\
\text { and ponds. }\end{array}$ \\
\hline Lst $1 \mathrm{v}$ & $\begin{array}{l}\text { Phytoherm } \\
\text { limestones of } \\
\text { stems (vertical) }\end{array}$ & $\begin{array}{l}\text { Boundstone of vertical stems } \\
\text { coated with calcite forming } \\
\text { palisades. The coatings show } \\
\text { concentric sparite with } 0.2-0.7 \mathrm{~cm} \\
\text { thick laminae. }\end{array}$ & $\begin{array}{l}\text { Tabular strata } 15-30 \mathrm{~cm} \text { thick } \\
\text { generally subhorizontal. }\end{array}$ & $\begin{array}{l}\text { Stems of reeds, rushes or other } \\
\text { macrophytes. }\end{array}$ & $\begin{array}{l}\text { Parts of the streams with } \\
\text { slow flow, banks of some } \\
\text { channels, ponds and } \\
\text { gentle-slope vegetated } \\
\text { areas. }\end{array}$ \\
\hline Lst $1 \mathrm{~h}$ & $\begin{array}{l}\text { Phytoherm } \\
\text { limestones of stem } \\
\text { (horizontal) }\end{array}$ & $\begin{array}{l}\text { Boundstone of horizontal stems } \\
\text { coated with calcite. }\end{array}$ & $\begin{array}{l}\text { The geometry is variable from } \\
\text { tabular to irregular. The thickness } \\
\text { does not exceed } 20 \mathrm{~cm} \text {. }\end{array}$ & $\begin{array}{l}\text { The stem direction is consistent } \\
\text { with other palaeocurrent structures. }\end{array}$ & Same as above. \\
\hline Lbg & $\begin{array}{l}\text { Bioclastic } \\
\text { limestones of } \\
\text { gastropods }\end{array}$ & Packstone/mudstone/floatstone. & $\begin{array}{l}\text { Tabular strata with decimetric } \\
\text { thicknesses. }\end{array}$ & $\begin{array}{l}\text { Structureless strata dominated by } \\
\text { gastropods. }\end{array}$ & $\begin{array}{l}\text { Deposition in slow flowing } \\
\text { areas with standing waters } \\
\text { along the streams and } \\
\text { ponds. }\end{array}$ \\
\hline Lbo & $\begin{array}{l}\text { Bioclastic } \\
\text { limestones of } \\
\text { oncoids }\end{array}$ & Packstone/mudstone/floatstone. & $\begin{array}{l}\text { Tabular strata with decimetric } \\
\text { thicknesses. }\end{array}$ & $\begin{array}{l}\text { Structureless strata with scattered } \\
\text { oncoids. }\end{array}$ & \\
\hline Lbch & $\begin{array}{l}\text { Bioclastic } \\
\text { limestones of } \\
\text { charophytes }\end{array}$ & Packstone/mudstone/floatstone. & $\begin{array}{l}\text { Tabular strata with decimetric } \\
\text { thicknesses. }\end{array}$ & $\begin{array}{l}\text { Structureless strata dominated by } \\
\text { charophyte gyrogonites and thallus. }\end{array}$ & \\
\hline Lph & $\begin{array}{l}\text { Phytoclastic } \\
\text { limestones }\end{array}$ & Rudstone of coated stem fragments. & $\begin{array}{l}\text { Lenticular strata with decimetric } \\
\text { thicknesses. }\end{array}$ & $\begin{array}{l}\text { Broken coated-stems of } \\
\text { macrophytes generally disordered. }\end{array}$ & $\begin{array}{l}\text { Moderate to fast flow } \\
\text { downstream phytoherm } \\
\text { limestones. Generally } \\
\text { occurs at the toe of } \\
\text { cascades, in gentle-slope } \\
\text { vegetated areas. }\end{array}$ \\
\hline Lo & $\begin{array}{l}\text { Oncolitic } \\
\text { limestones }\end{array}$ & $\begin{array}{l}\text { Rudstone of oncoids with spheric to } \\
\text { cylindrical morphologies and } \\
\text { millimetre to centimetre sizes. The } \\
\text { matrix is composed of micrite and } \\
\text { silt to sand quartz grains. }\end{array}$ & $\begin{array}{l}\text { Amalgamated lenticular to tabular } \\
\text { beds } 50 \text { to } 80 \mathrm{~cm} \text { thick, and few } \\
\text { metres long. }\end{array}$ & $\begin{array}{l}\text { Internal lamination is rare. } \\
\text { Gastropod fragments and } \\
\text { phytoclasts are common. Quartzite } \\
\text { clasts are common in the nuclei. }\end{array}$ & $\begin{array}{l}\text { Slow to moderate flow in } \\
\text { streams and/or ponds. }\end{array}$ \\
\hline B & Carbonate breccias & $\begin{array}{l}\text { Clast-supported, decimetric tufa } \\
\text { fragments. }\end{array}$ & $\begin{array}{l}\text { Discontinuous wedge-shaped } \\
\text { strata with thicknesses from dm to } \\
1 \mathrm{~m} \text {. }\end{array}$ & $\begin{array}{l}\text { Non-sorted angular fragments and } \\
\text { blocks. }\end{array}$ & $\begin{array}{l}\text { Eroded or collapsed of tufas } \\
\text { at the toe of cascades. }\end{array}$ \\
\hline Lsp & $\begin{array}{l}\text { Speleothem } \\
\text { limestones }\end{array}$ & Laminated sparite. & $\begin{array}{l}\text { Different shapes and sizes. } \\
\text { Generally decimetric. }\end{array}$ & $\begin{array}{l}\text { Stalactites, stalagmites, subaqueous } \\
\text { laminated carbonate. }\end{array}$ & $\begin{array}{l}\text { Caves developed below the } \\
\text { cascades. }\end{array}$ \\
\hline Cct & Calcretes & Nodular to massive. & Tabular with $50-150 \mathrm{~cm}$ thick. & Rhizocrection. & Palaeosols \\
\hline M & Mudstones & Clay and silts. & $\begin{array}{l}\text { Tabular and lenticular. Decimetric } \\
\text { to metric thickness. }\end{array}$ & Structureless. & $\begin{array}{l}\text { Overbank deposits in } \\
\text { floodplains. }\end{array}$ \\
\hline S & Sandstones & $\begin{array}{l}\text { Medium to coarse grain size. } \\
\text { Composed of quartz and carbonate } \\
\text { clasts. Cemented by carbonate. }\end{array}$ & $\begin{array}{l}\text { Lenticular and channel fill } \\
\text { geometries. }\end{array}$ & Cross-stratification. & $\begin{array}{l}\text { Channel and overbank } \\
\text { deposits }\end{array}$ \\
\hline G & Conglomerates & $\begin{array}{l}\text { Clast supported. Angular to } \\
\text { subangular clasts of quartzite } \\
\text { recycled from Paleogene } \\
\text { conglomerates. }\end{array}$ & $\begin{array}{l}\text { Wedge shape and lenticular } \\
\text { geometries. }\end{array}$ & Structureless. & $\begin{array}{l}\text { Alluvial deposition in } \\
\text { channels and/or flash } \\
\text { floods. }\end{array}$ \\
\hline
\end{tabular}

Table 2

Facies proportion obtained during facies modelling for the whole tufa and for the carbonate sedimentary units.

\begin{tabular}{lccccc}
\hline Facies & \% Peña del & $\%$ & $\%$ & $\%$ & $\%$ \\
& Manto & SU-1 & SU-3 & SU-5 & SU-6 \\
\hline $\begin{array}{l}\text { Phytoherm limestones of } \\
\quad \text { bryophytes }\end{array}$ & 42.98 & 32.8 & 43.63 & 63.82 & 65.2 \\
$\begin{array}{l}\text { Phytoherm limestones of stems } \\
\text { Phytoclastic limestones }\end{array}$ & 12.12 & 38.3 & 10.8 & 36.18 & 17.2 \\
Bioclastic limestones & 1.43 & 2.4 & 1 & & 9.32 \\
$\begin{array}{l}\text { Oncolitic limestones } \\
\text { Carbonate breccias }\end{array}$ & 20.22 & 3.2 & 29.37 & 0 & 0.61 \\
$\quad \begin{array}{l}\text { Mudstones. Sandstones and } \\
\quad \text { conglomerates }\end{array}$ & 7.87 & 15.65 & 9 & 0 & 5.92 \\
& 0.33 & 1.85 & 0 & 0 & 1.75 \\
& 15.05 & 5.8 & 6.2 & 0 & 0
\end{tabular}

and SU-6. 3) located in the upper part of Section 6 and comprising SU-5 strata (Figs. 2, 4, 5).

\subsubsection{Sedimentary unit description}

Sedimentary unit (SU) 1 crops out in the northern gully. It lies unconformably on Paleogene deposits and is overlain by sedimentary units 2 and 3 (Figs. 4, 5, 6). This sedimentary unit is $4 \mathrm{~m}$ thick and extends $200 \mathrm{~m}$ along the north gully and $50 \mathrm{~m}$ laterally. Internally, it consists of very gently (about $5^{\circ}$ ) westward-dipping tabular strata forming downlap contacts (Fig. 4). The easternmost part of SU-1 comprises up to $20^{\circ}$ westward-dipping strata with lenticular geometries (around section $\mathrm{M}$ ) that downslope pass rapidly into gently dipping strata (Figs. 4, 5). 

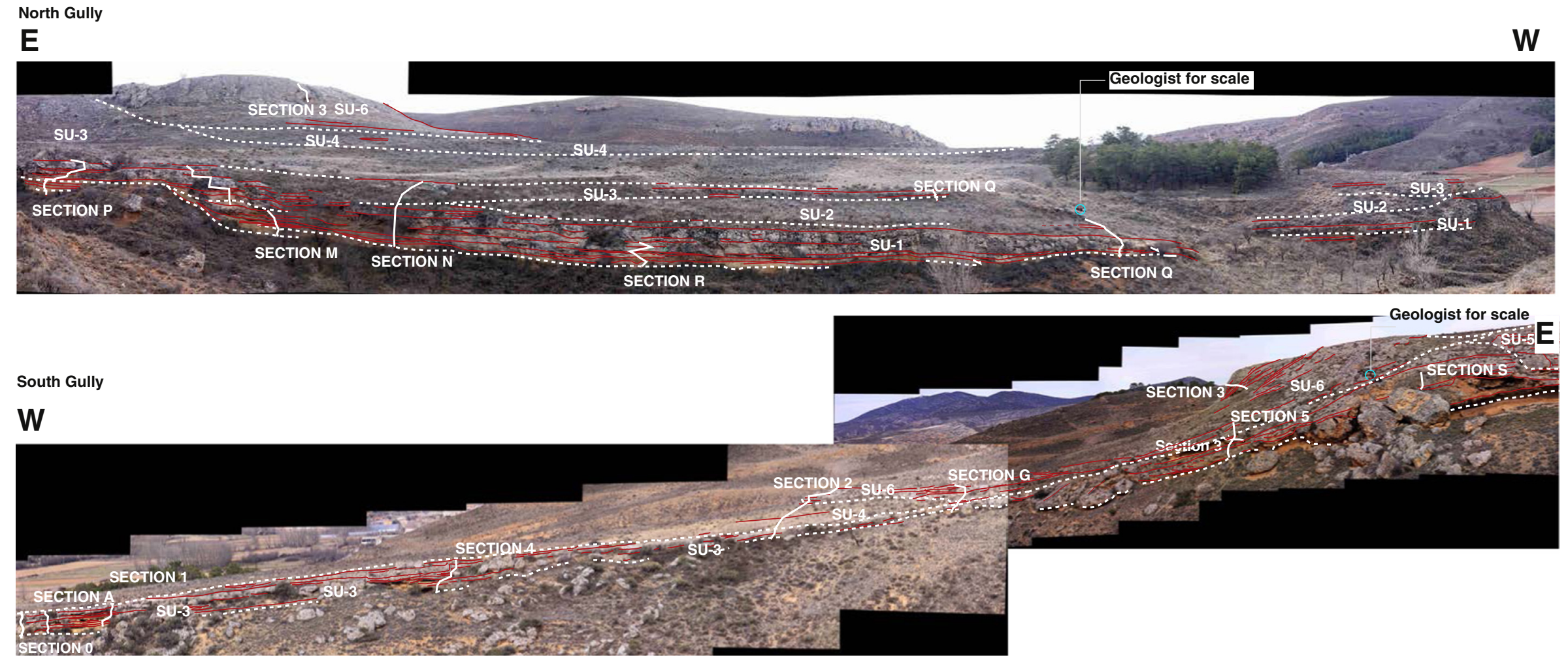

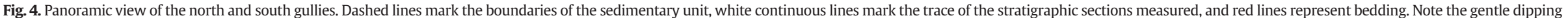
downlaps in the north gully (marked by arrows). (For interpretation of the reference to colour in this figure legend, the reader is referred to the web version of this article.) 


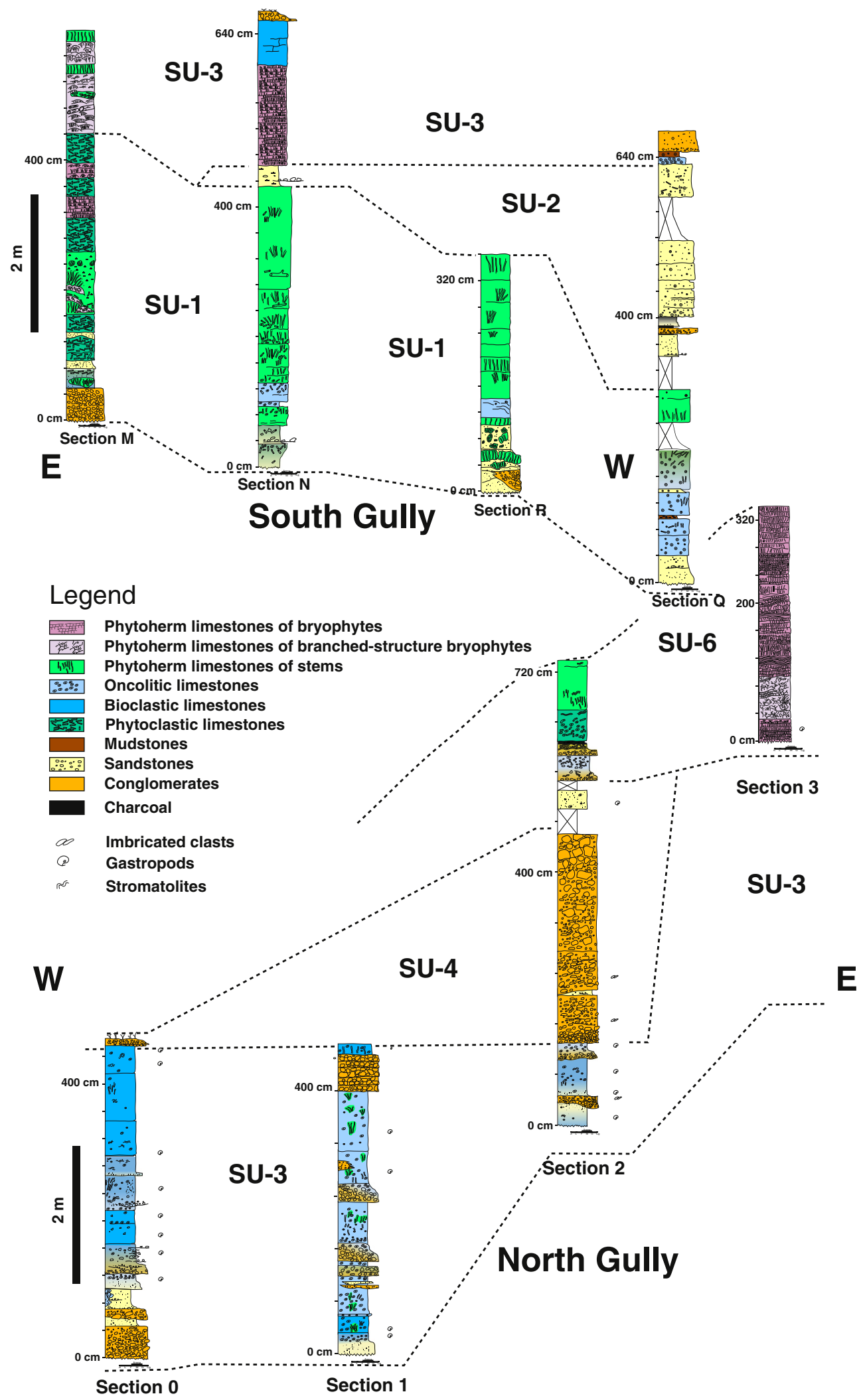

Fig. 5. Correlation panel for some sections of the north and south gullies. Dashed lines are the correlation lines.

Sedimentary unit 2 crops out in the northern gully. It lies disconformably on SU-1 and is overlain by SU-3. Its geometry is lenticular and pinches out laterally, up and downslope in the northern gully (Figs. 4, 5, 6). Their extension is reduced, $110 \mathrm{~m}$ long in the gully direction (E-W) and about $50 \mathrm{~m}$ wide in $\mathrm{N}-\mathrm{S}$ trend (Fig. 6). This unit is composed of clastic deposits including mudstones, sandstone and conglomerates which can contain oncoids. Charcoal-rich mudstone beds occur at the base of conglomerate-sandstone channel fills.

Sedimentary unit 3 is very extensive, outcropping along the whole Peña del Manto and exceptionally exposed in the $\mathrm{N}$ and $\mathrm{S}$ gullies. It 


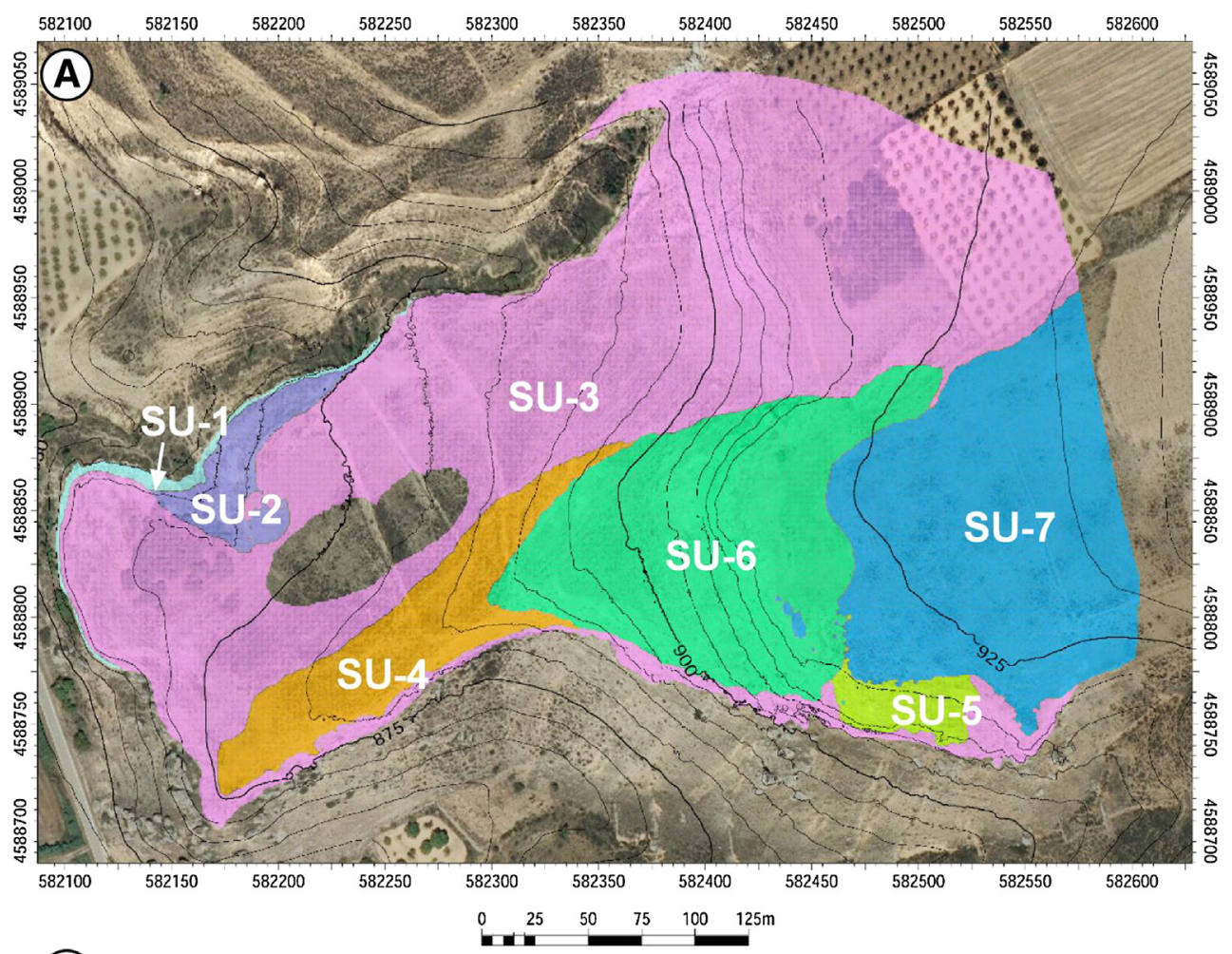

(B)

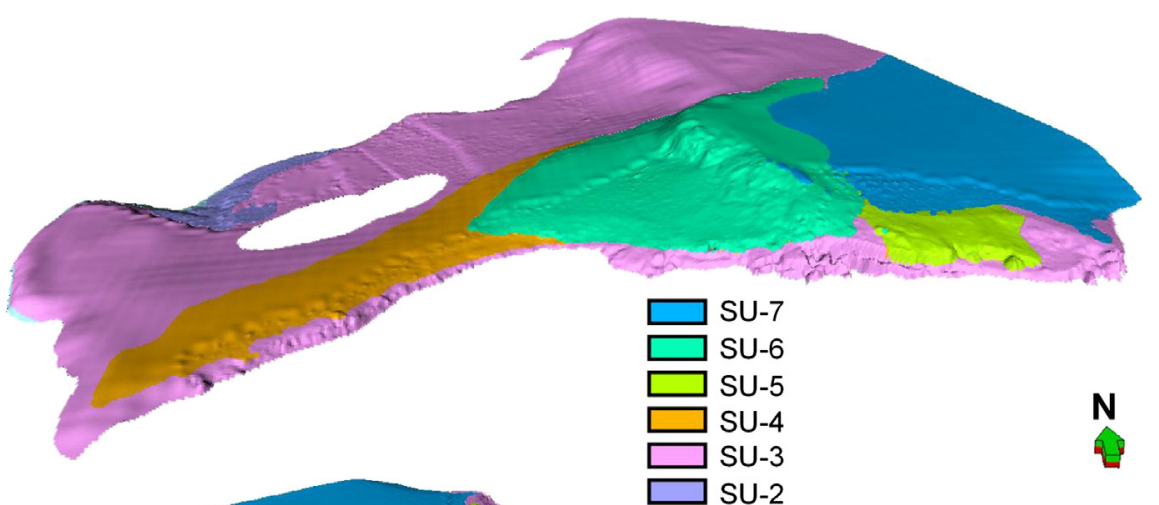

(C)

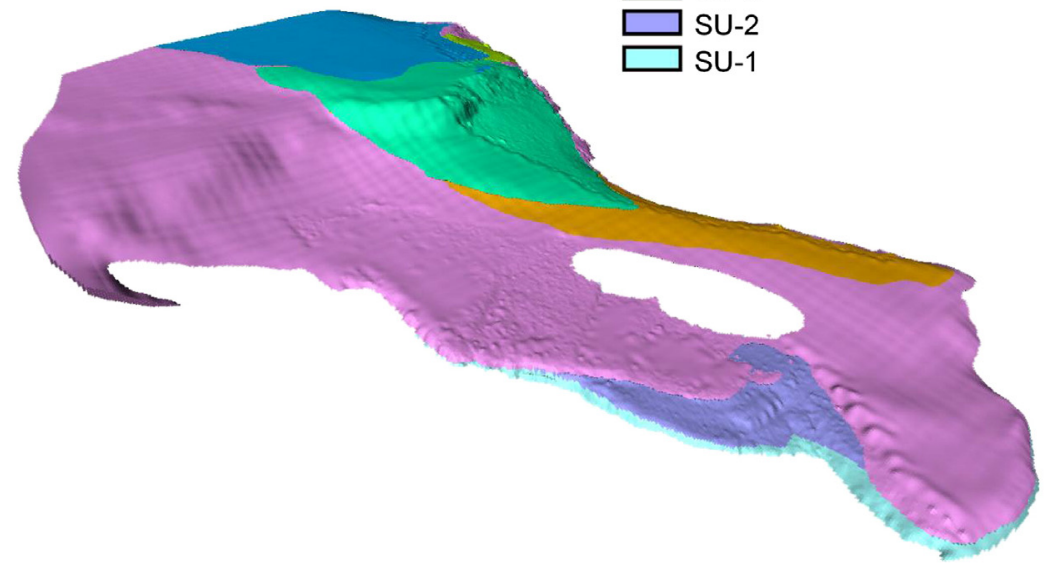

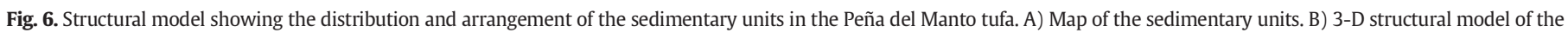
Peña del Manto DOM seen from the south. C) 3-D structural model seen from the north.

lies unconformably on the Paleogene rocks, SU-1, and SU-2, and is overlain by SU-4, 5, 6 and 7 (Figs. 4, 5, 6). The geometry of this unit is that of two connected wedges that open westward, one connected from sections $\mathrm{F}$ to S, and the other from sections 2 to 0 (Figs. 2, 6). At the westernmost part of the south gully the unit is eroded and forms a cliff which connects with the Henar floodplain (Fig. 2). It comprises both sub-horizontal tabular strata with vertical stacking from section 2 to section 0 (Figs. 4, 5; south gully), and steeply $\left(15-60^{\circ}\right)$ dipping lenticular strata forming large (decametric) stacked foresets defining a progradational/aggradational trend (Fig. 5).

Sedimentary unit 4 disconformably overlies SU-3 in the proximities of the southern gully with a wedge geometry, covered by SU- 6 at their 
eastern-most outcrops (Figs. 4, 5, 6). Its maximum thickness is $4.5 \mathrm{~m}$ and wedges out gradually to the west but more abruptly to the east. It is made up mainly of quartzite-clast conglomerates $(C-20 \mathrm{~cm})$, while internal strata surfaces are not recognizable.

Sedimentary unit 5 has reduced extension, outcropping only in the south gully and shows a concave-upwards base and a lenticular geometry. It wedges out to the north (Fig. 6), and its base is unconformable above SU-3, while laterally becoming conformable. In turn, this unit is covered by SU-6 and 7. Internally, SU-5 has steeply dipping and southward prograding strata that downlap the basal unconformity developed above SU-3.

Sedimentary unit 6 crops out in the eastern half of Peña del Manto and shows a sigmoid geometry that pinches out to the east and west (Figs. 4, 5, 6). This unit unconformably overlies SU-3, 4 and 5. It is overlain by small patches of SU-7 in the upper part of the tufa (Fig. 6). Internally it is made up of inclined strata, which become steeper upwards $\left(30^{\circ}-80^{\circ}\right)$, progrades to the west and becomes in this direction gently dipping strata $\left(10-15^{\circ}\right)$ (Fig. 5).

Sedimentary unit 7, exposed in the eastern half of Peña del Manto, is lying unconformably on SU-3, 5 and 6. SU-7 is mainly composed of structureless quartzite-clast conglomerates. It has wedge geometry and its thickness reaches $5 \mathrm{~m}$, pinching out towards the west (Fig. 6).

\subsection{Facies description}

In this paper we have followed the facies code of Arenas-Abad et al. (2010) with minor modifications (see Table 1 and the summarized facies description) to identify facies. Here we describe facies identified in Peña del Manto.

Siliciclastic facies identified are: 1) muds (muds and marls), 2) sandstones ( $\mathrm{Sm}, \mathrm{St}, \mathrm{Sp}$ ), and 3) quartzite-clast conglomerates ( $\mathrm{Cg}, \mathrm{Gms}, \mathrm{Gp}$ ) are not described below, to focus on carbonate facies.

\subsubsection{Phytoherm limestones of bryophytes}

These deposits include two facies: Phytoherm limestones of bryophytes (Lbr) and phytoherm limestones of branched-structure bryophytes (Lbra).

Lbr facies is made up of isopachous to wedge-shaped sigmoidal layers that stack vertically and laterally (in decameter scale) with thickness ranging between $2-$ and $10-\mathrm{cm}$ (Table 1 ). The bryophyte forms a very tight structure including some vertical voids among the moss structure (Fig. 7A).

Branching bryophytes (Lbra) show globular or bush-like geometries and generally occur below $\mathrm{Lnr}$ facies. Internally they have an open structure with non-parallel branches that cross among them (Fig. 7B).

Bryophytes associate commonly with insect tubes, which are generally curved, and are $3-4 \mathrm{~cm}$ long with an approximately $0.5 \mathrm{~cm}$ diameter. Lbra appears at the base while Lbr covers Lbra and is the most widespread facies in these deposits. Although Lst $1 \mathrm{~h}$ and Lst $1 \mathrm{v}$ sometimes are associated with Lph, in general Lbr and Lbra are the only facies that make up these deposits.

\subsubsection{Phytoherm limestones of stems}

These deposits include several facies: phytoherm limestones of stems (vertical) (Lst 1v), phytoherm limestones of stems (horizontal) (Lst 1h), phytoherm limestones of charophytes (Lch). These facies laterally grade between them, although Lch is very scarce.

Lst $1 \mathrm{v}$ and Lst $1 \mathrm{~h}$ facies are boundstones of encrusted macrophytes (Fig. 7C). Both facies form strata with tabular geometry and high lateral continuity. These deposits are commonly associated with phytoclastic (Lph) and bioclastic (Lbg, Lbo, Lbch) limestones and appear in subhorizontal strata.

\subsubsection{Bioclastic limestones}

These are mainly composed of bioclastic limestones of gastropods (Lbg), bioclastic limestones of oncoids (Lbo), bioclastic limestones of charophytes (Lbch), which grade laterally and vertically between them. These deposits usually form decimetre to metre-thick tabular strata with low angle $\left(5^{\circ}-10^{\circ}\right)$ or subhorizontal disposition. These deposits are commonly associated with Lst $1 \mathrm{v}$, Lst $1 \mathrm{~h}$, oncolitic limestones (Lo), conglomerates and sandstones (see Table 1).

\subsubsection{Phytoclastic limestones}

These are mainly made up of Lph facies (Table 1; Fig. 7D) in lenticular strata with decimetric thickness and metric length. Lst $1 \mathrm{v}$, Lst $1 \mathrm{~h}$, and oncolitic limestones (Lo) are also present in these deposits in minor proportions. These deposits are associated vertically and laterally with carbonate breccias.

\subsubsection{Oncolitic limestones}

They are made up mainly of rudstones of millimetric to centimetricsized oncoids (Lo) with fine-grained carbonate matrix, phytoclasts are also present (Fig. 7E). These deposits commonly form stacked lenticular to tabular beds 0.5 to $0.8 \mathrm{~m}$ thick a few metres in length. These deposits occur in subhorizontal or low-dip strata, and are associated with Lbo, Lbg, Lbch, Lst 1v, Lst 1h, Lph and conglomerates.

\subsubsection{Carbonate breccias}

They are commonly located at the toe of steep slopes. They consist of a chaotic mix of angular decimetre-sized fragments derived from the destruction of tufa deposits, mostly Lbr and Lst in a minor proportion (Fig. 7F). They constitute discontinuous wedge-shaped beds from a few decimetres to almost $1 \mathrm{~m}$ in thickness.

\subsubsection{Speleothem limestones}

They are crystalline calcite precipitates that occur in cavities or sheltered areas. They mainly consist of stalactites, stalagmites, botryoidal and laminated crystalline calcites precipitated on steep slopes covering the inner parts of cavities (Fig. 7G).

\subsubsection{Calcretes}

Calcretes are nodular and massive beds, ranging from $50-$ to $150-\mathrm{cm}$ in thickness, displaying a white to beige colour. They are present locally at the base of the Peña del Manto tufa in upstream sections and are developed on brown siltstones with quartzite clasts of the Paleogene substrate (Fig. 7H).

\subsection{Architectural elements}

Three main architectural elements with different geometries, dips and facies have been identified in Peña del Manto.

\subsubsection{Steeply dipping strata dominated by phytoherm limestones of bryo- phytes (SSLbr) \\ In Peña del Manto several steeply dipping strata dominated by bryo-} phyte phytoherm limestones have been identified, representing nearly $20 \%$ of the area of the tufa and more than $50 \%$ of the total volume (Fig. 8A). The SSLbr is found on present-day steep terrain slopes. Height of steps ranges from 6 - to $25-\mathrm{m}$, and are made up of prograding and aggrading strata dipping from $20^{\circ}$ to $75^{\circ}$ (Fig. $8 \mathrm{~B}, \mathrm{C}$ ). Dip of the aggrading-prograding strata increases from base to top reaching in some cases up to $80^{\circ}$, constituting hemi-domic bodies. In the south gully, metric domes of bryophyte phytoherms occur along an irregular surface at the base of SSLbr (Fig. 8C). Strata display sigmoidal geometries showing their maximum thickness in the centre of S, where dip angle is higher. Thickness reduces progressively upwards and downwards as dip of the strata decreases (Fig. 8B, C). The SSLbr are made up mainly of Lbr facies and at their base bush-like bodies occur, made up of Lbra facies (Figs. 5, 8B, D). Larval tube structures, tree-trunk mould and leaf remains are common. Lph, Lst 1, sands and 

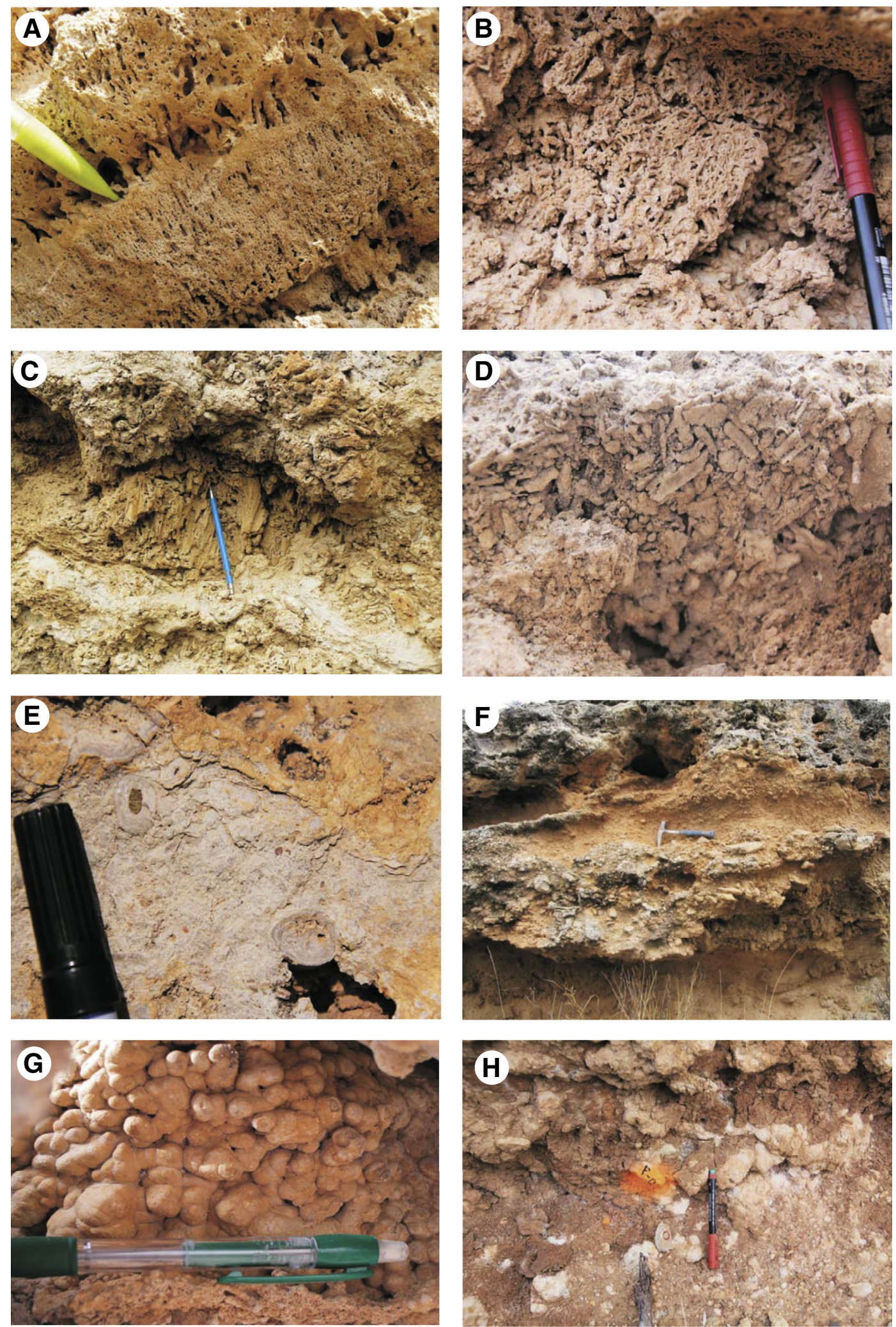

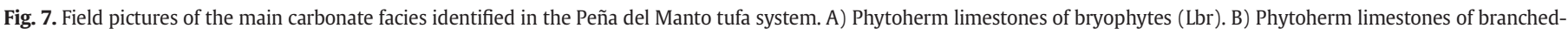

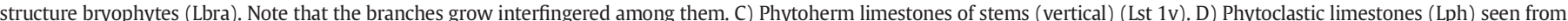

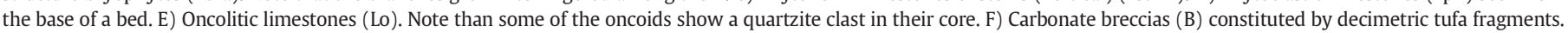
G) Speleothem limestones (Lsp) in the internal walls of a cavity. H) Nodular calcrete at the base of the Peña del Manto tufa deposits.

conglomerates can also be present, but in minor amounts grading laterally to Lbr facies. These tree moulds occur as large tubes parallel to stratification that preserve marks of the cortex and broken branches. Some tree moulds reach 3-m long and $50-\mathrm{cm}$ in diameter. There is a lack of evidence of hanging vegetation or curtains. Below some strata, small $0.25-$ $2-\mathrm{m}^{3}$ caves with Lsp facies are preserved. 

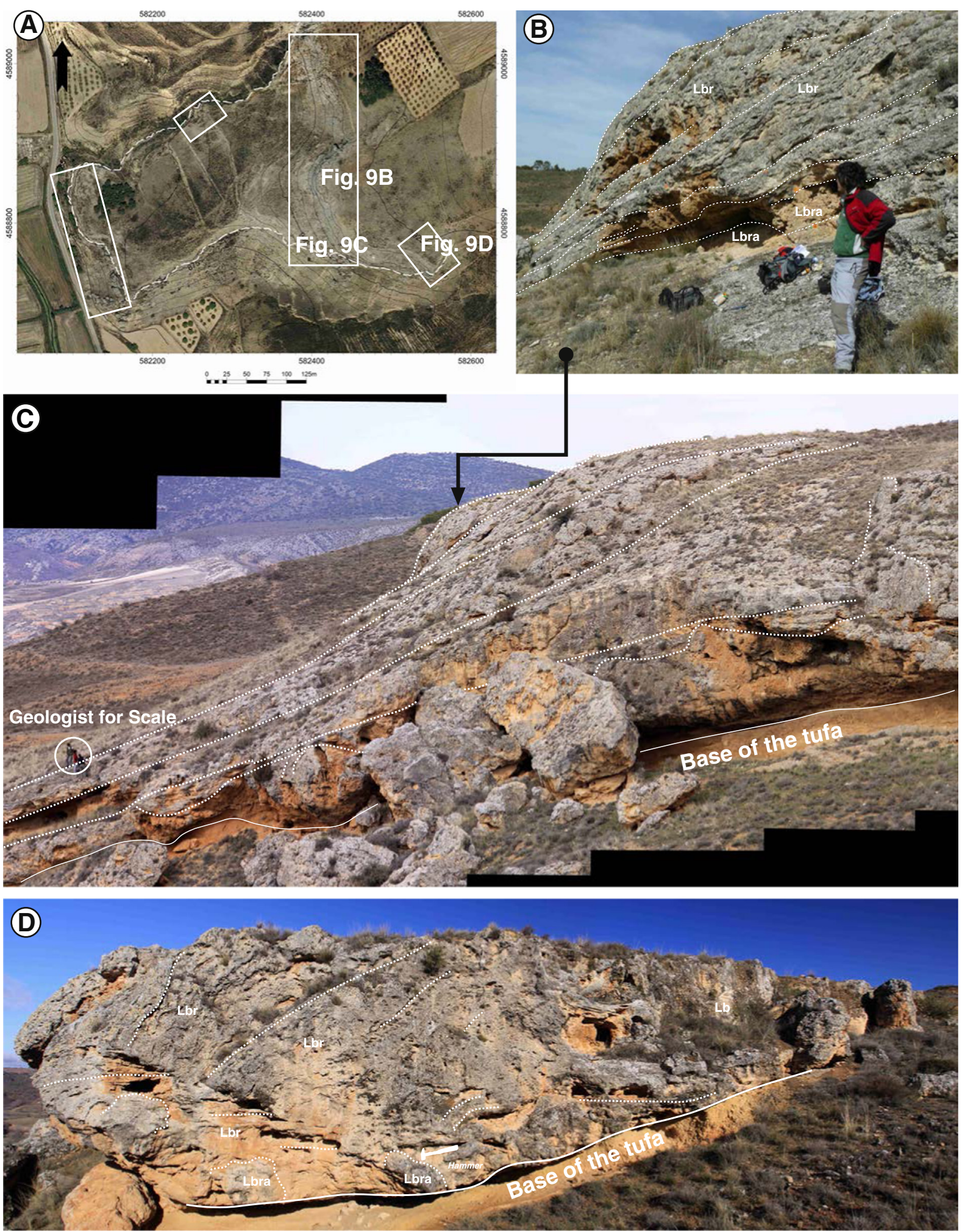

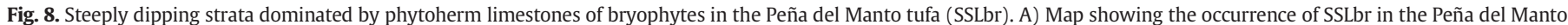

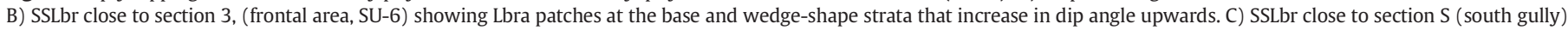
evidencing the increase in slope from the base to top of the tufa. D) SSLbr close to section F (south gully; SU-3).

4.3.1.1. Interpretation. The SSLbr are interpreted as cascade environments, one of the most carbonate precipitating areas in tufas due to $\mathrm{CO}_{2}$ degassing and consequent carbonate precipitation from water (Pedley, 1990; Drysdale and Head, 1994; Auqué et al., 2014). Cascades were dominated by bryophyte growth that would initially have created mounds covered by moss layers. Aggradation and progradation of moss layers increased the cascade slope. Caves formed in sheltered areas that after cascade progradation and continuous cascade development were finally closed, as identified in other tufas (Vázquez-Urbez, 2008; Arenas-Abad et al., 2010). In some cases the aggradation/progradation of cascades could have dammed small areas upstream, as suggested by the presence of subhorizontal strata dominated by Lb and Lst $1 \mathrm{v}$ facies. 
4.3.2. Gently dipping strata dominated by phytoherm limestones of stems (GSLst)

Gently dipping strata dominated by phytoherm limestones of stems are constituted by strata with wedge geometry that dip around $8^{\circ}-15^{\circ}$. These deposits occur at the toe of the SSLbr and cover around $20 \%$ of the area of the tufa, representing nearly $10 \%$ of total rock volume. These deposits are dominated mainly by Lst $1 \mathrm{v}$, Lst $1 \mathrm{~h}$, and Lo. Lph and Lbr facies are also present, but in minor amounts. In addition, clastic deposits (sandstones, conglomerates and breccias) form decimetre-thick wedges, lenses and small channel fills.

4.3.2.1. Interpretation. The GSLst are interpreted as gentle-slope, vegetated areas located at the toe of cascades. Facies suggest that these areas were dominated by vegetation and small streams that favoured oncoid formation. Dip angle of these deposits indicates the depositional slope, and presence of conglomerates and sandstones suggest that water flow was active in these areas. Similar environments have been described in other tufas (Das and Mohanti, 2005; Arenas et al., 2014).

\subsubsection{Horizontal strata dominated by bioclastic and oncolitic limestones (HSLbLo)}

Horizontal strata dominated by bioclastic and oncolitic limestones occur immediately at the back side (opposite to progradation direction) of SSLbr deposits and at the toe of GSLst. HSLbLo are tabular deposits dipping less than $3^{\circ}$ composed of Lbo, Lbg, Lo, and also Lst $1 \mathrm{v}$, Lst $1 \mathrm{~h}$, and sandstones and conglomerates in minor proportions. Fossil content is dominated by gastropods, macrophyte remains. Conglomerates occur in decimetre-thick lenses intercalated in Lb facies.

HSLbLo, which are 50-150 m wide and $150 \mathrm{~m}$ long, represent $56.8 \%$ of the tufa area and around 30\% of total rock volume.

4.3.3.1. Interpretation. HSLbLo are interpreted as ponds and/or streams with pools. Ponds would have developed as a consequence of lateral and vertical growth of cascades, which formed small barrages that created areas with slow-flowing water upstream of the cascade. This process has been described in other tufas (Vázquez-Urbez, 2008; Pedley, 2009; Arenas-Abad et al., 2010; Arenas et al., 2014). Streams with pools or slow-flowing waters could have formed in areas (or moments) where the aggradation/progradation ratio of the cascade is less than 1 , but lakes cannot be developed, as suggested by Arenas et al. (2014). In the streams oncolitic limestones formed, while in areas with slow-flowing waters bioclastic limestones were deposited. The quartzite-clast conglomerates present in some HSLbLo come from lateral Paleogene reliefs.

\subsection{Electric resistivity tomography (ERT)}

Two ERT profiles perpendicular to each other were measured with different trends: a W-E-trending profile parallel to the north and south gullies (Profile 1 ), and a N-S-trending profile connecting tufa exposures in the two gullies (Profile 2) (Fig. 2).

In these profiles, resistivity varies notably from 30 to $90,000 \Omega \cdot \mathrm{m}$. Three zones can be distinguished on the basis of the recorded resistivity values (Fig. 9).

Zone 1 is located just below surface and is $1-2$ m-thick. Resistivities range between 200 and $400 \Omega \cdot \mathrm{m}$ along both profiles.

Zone 2 . Below Zone 1 resistivities increase notably down to 12 to $30 \mathrm{~m}$ depth, reaching values between 900 and $90,000 \Omega \cdot \mathrm{m}$. The top of this zone is parallel to the terrain surface, but its base is more irregular. In steep-slope areas (255-340 $\mathrm{m}$ from the $\mathrm{W}$ termination of profile 1 ) the high resistivity zone increases in thickness and reaches highest resistivities in the tufa that coincides with a deflection at the base of Zone 2 (Fig. 9). In profile 2, two levels (about 10- to 15-m thick) with high resistivity values $(>1600 \Omega \cdot \mathrm{m})$ display a concave-upwards section wedging out towards the central part of the profile. These levels are recognized in the south and north parts of profile 2, disconnected by a low resistivity area in the centre (Fig. 9). In the most western part of profile 1
(12-48 $\mathrm{m}$ from the $\mathrm{W}$ termination of the profile) resistivities decrease to values of about $300 \Omega \cdot \mathrm{m}$.

Zone 3 , the deepest zone observed, is characterized by low resistivity values $(20-300 \Omega \cdot \mathrm{m})$ (Fig. 9).

\subsubsection{Interpretation}

Correlation between ERT profiles and surface geology allow us to mark sedimentary unit boundaries as well as apparent bed dips in interpreted profiles.

Low resistivity values, the 1-2 m thickness of Zone 1 and the correlation with outcrop data allow us to interpret this zone as conglomeratic colluvial deposits and soils covering the tufa. Zone 2 is interpreted as tufa, from correlation with outcrops, and because of the high resistivity values of this kind of porous carbonates (De Filippis et al., 2013; Ögrretmen and Seren, 2014). The more porous the tufa facies, the greater their resistivity. The highest values registered, from $30,000 \Omega \cdot m$ to infinite, are interpreted as caves developed in a dry or vadose environment, due to the high resistivity values of air (Fig. 9). This high resistivity anomaly produces a deflection at the base of Zone 2 that could be a step in the basement topography (around $350 \mathrm{~m}$ from $\mathrm{W}$ termination). The decrease in resistivities in the western termination of profile 1 is interpreted as due to the presence of clastic deposits of SU-2. The disconnection of the two high resistivity levels of profile 2 is interpreted as an area with no tufa deposition, where Zone 3 crops out.

Low resistivity values of Zone 3 correspond to the siliciclastic basement of Barranco de Valdehurtado Fm., the bedrock of Peña del Manto tufa (Fig. 9).

\subsection{Facies modelling results}

The Peña del Manto facies model is based on a DOM of an exceptional-quality outcrop and on a well-constrained conceptual model that could serve to improve the understanding of facies distribution in this kind of non-marine carbonate system (Fig. 10). Upscaled cells, all the 3-D model cells that have a property value assigned based on hard data (stratigraphic sections, local observations and facies distribution map), can be used in the facies modelling process interpolated with different geostatistical methods. Comparison between the abundance of every facies in the sections and in the facies model cells reveals differences especially in the phytoherm limestones of bryophytes. This is produced by the deterministic modelling carried out with facies map data, the ubiquitousness of phytoherm limestones of bryophytes in the steeply dipping strata which have large outcrops and great thicknesses recorded in these areas (Fig. 10).

The facies distribution in the model shows the predominance of phytoherm limestones of bryophytes, about $43 \%$ of the volume of the Peña del Manto tufa. Bioclastic limestones represent 20\%, phytoherm limestones of stem $12 \%$, oncolitic limestones about $8 \%$, and phytoclastic limestones $1.4 \%$ of total rock volume. Clastics are about $15 \%$ and are dominated by conglomerates (Fig. 10; Table 2).

The spatial distribution of facies, the geometry and stacking patterns of strata helps to characterize the architectural elements (Fig. 10; Table 3). 1) SSLbr are made up almost exclusively of Lbr and Lbra facies ( $90 \%$ of rock volume), and represent nearly $20 \%$ of the area of the tufa. 2) GSLst are mainly composed of phytoherm limestones of stem (38\%), oncolitic limestones (31\%) and phytoclastic limestones (15\%). 3) HSLbLo are made up of bioclastic limestones (45\%), oncolitic limestones (30\%) and phytoherm limestones of stem (17\%).

\section{Discussion}

\subsection{The Peña del Manto sedimentary model}

Tufas have been classified in different sedimentary models based on the geomorphological context where they are developed, their morphology, and their characteristic deposits or facies associations 
(A)
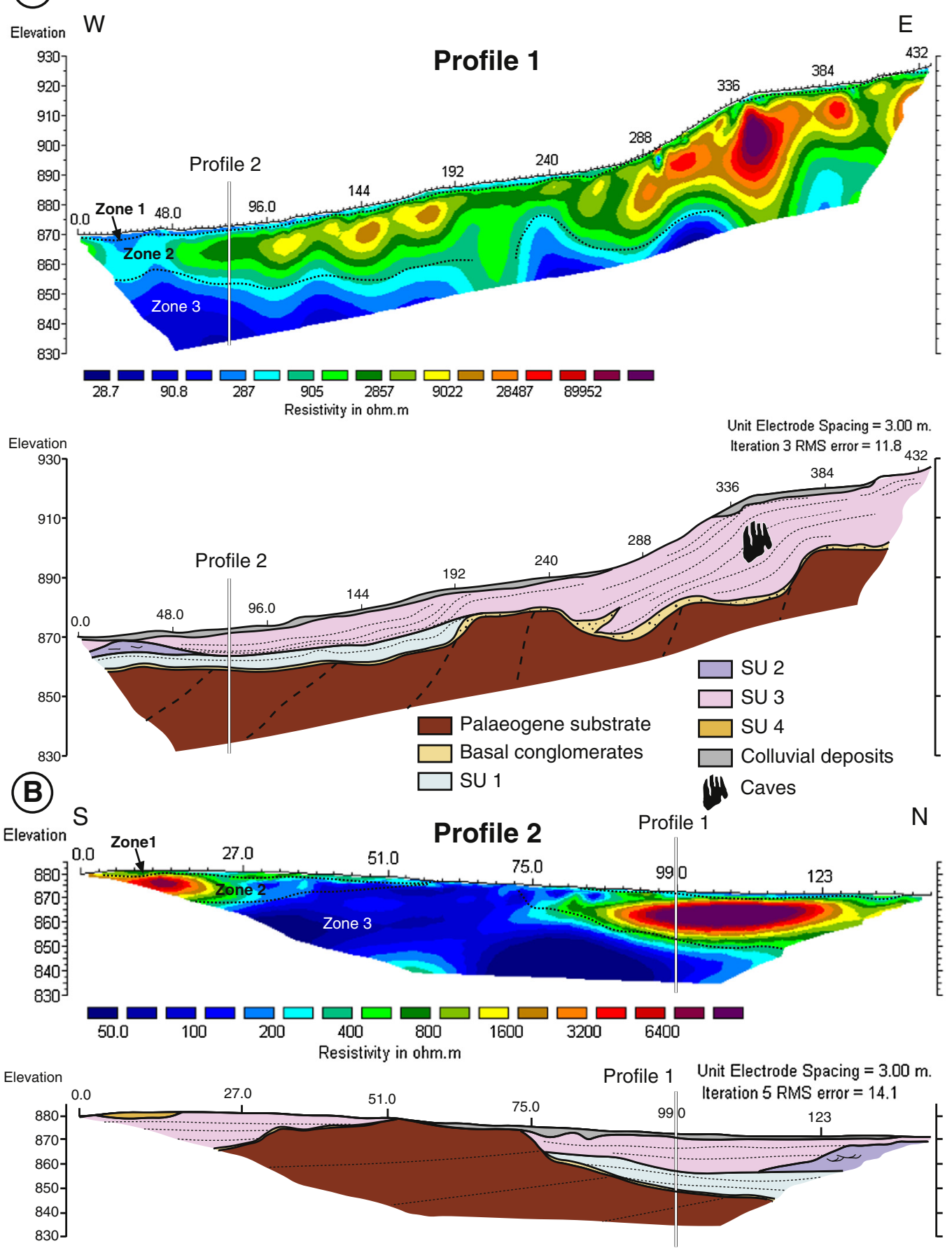

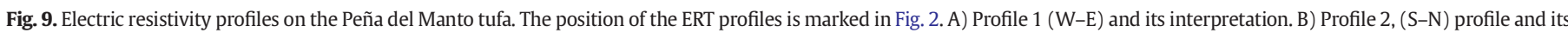
interpretation. The zones marked by dashed lines represents the different resistivity domains identified in the profiles.

(Pedley, 1990; Pentecost and Viles, 1994; Pedley, 2009; Arenas-Abad et al., 2010). According to these models, the Peña del Manto could be classified either as cascade tufa, because at least 3 well-developed major cascades are present. Nevertheless, here we consider classifying the Peña del Manto to be more useful as a high-gradient and stepped fluvial tufa system, in the sense of Arenas-Abad et al. (2010), which can comprise several elements of the classical tufa models (Pedley, 1990; Pentecost and Viles, 1994).

The Peña del Manto Tufa could be sourced by one or several springs located along the Mesozoic-Paleogene contact, where most springs in the area occur (Yélamos and Sanz Pérez, 1998), which was located above the easternmost outcrops of the tufa. During most of its history, the tufa was composed of: 1) cascades dominated by bryophytes, with dead tree moulds, small caves and insect larval structures similar to others identified in tropical (Carthew et al., 2003; Drysdale et al., 2003) and temperate climates (Brasier et al., 2011).

2) Vegetated areas at the toe of cascades that graded downflow to 3) streams with areas of slow-flowing waters and small ponds. Progradation/aggradation of cascades allowed the formation of slowflowing waters and/or upstream-related ponds. 


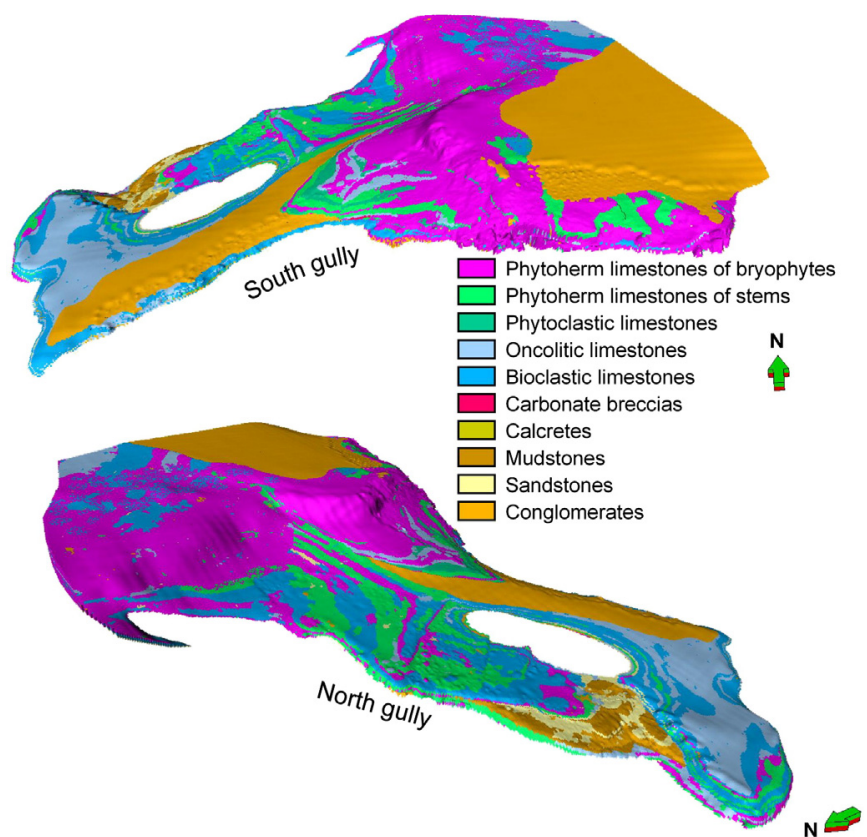

Fig. 10. 3-D facies model of the Peña del Manto tufa seen from the south (upper part) and from the north (lower part).

\subsection{Bedrock control of cascade generation}

The Peña del Manto tufa develops along the left side of the Henar river on the Barranco de Valdehurtado Fm., made up of quartzite-clast conglomerates and mudstones. Outcrops of this formation show ramp morphology with small steps corresponding to the occurrence of more resistant conglomerate beds. This ramp morphology is also observed at the base of the tufa in the southern gully (Figs. 4, 8C). The ERT profile 1 (E-W directed) shows a deflection at the base of Zone 2 (350 $\mathrm{m}$ from $\mathrm{W}$ ) that can be produced by the high resistivity anomaly, interpreted as a cave, but could correspond with a non-vertical step in bedrock as well (Fig. 9). As observed in the south gully, occurrence of the main cascade of SU-3 developed on a ramp with a $12^{\circ}$ slope that allowed generation of small phytoherms of bryophytes (Fig. 9), constituting small jumps along the ramp, favouring $\mathrm{CO}_{2}$ degassing from water. These irregular surfaces made up of successive jumps are similar to the ramp growth style described by Arenas et al. (2014) (Fig. 13A). Progressive tufa aggradation and progradation generated steep-slope cascades that reached strata dips of about $80^{\circ}$, exaggerating the initial topography. In the case of Peña del Manto the cascades do not coincide neither with important changes in bedrock lithology, as occurs in the Añamaza river (Arenas et al., 2014) nor with fault scarps, as occurs in the Tortajada fluvial system (Camuera et al., 2015).

\subsection{Evolution of the Peña del Manto}

The Peña del Manto tufa was developed probably during the Middle and/or Late Pleistocene as were other nearby tufa deposits in the Iberian ranges, like those in the Añamaza, Mesa and Piedra Rivers (Vázquez-Urbez, 2008; Arenas et al., 2010; Sancho et al., 2010). The tufa developed in a small gully excavated along the east side of the Henar river paleo-valley. This gully showed two irregular gentle slope areas, connected by two scarps, as deduced from a reconstruction of the basal surface of the tufa (Figs. 5, 6). Increase in water agitation along these two steeper areas or scarps triggered $\mathrm{CO}_{2}$ degassing and favoured calcite precipitation, which led to tufa nucleation and cascade formation (Lorah and Herman, 1988; Drysdale and Gillienson, 1997).

Six evolution stages are recognized:

1) During the first stage (SU-1) tufa deposition in the Peña del Manto followed the trace of the present day northern gully (Fig. 11A). This unit records the deposits of a small cascade around section $\mathrm{M}$, and another one around Nogales section (see Fig. 2 for location). Between these two cascades, water flowed across a low-slope vegetated area with local ponds. The downlap relationship observed between strata of SU-1 and the basal unconformity is evidence of downstream expansion of the tufa (Fig. 4).

2) The second stage (SU-2) is recorded by a major clastic input (G, S, and $\mathrm{M}$ facies) in the northern gully, which drastically reduced tufa growth (Fig. 11B).

3) During the third stage (SU-3) Peña del Manto tufa reached its maximum areal extension (a surface around $70,000 \mathrm{~m}^{2}$ ) (Fig. 10C). At least 3 major cascades developed (from west to east: 1) around Nogales section, 2) around section $\mathrm{G}$ and 3 ) around section F, see Figs. 2 and $8 \mathrm{~A}$ ) separating two stretches of the stream with very gentle slopes. During this stage the main stream diverted around a small $(100 \times 40 \mathrm{~m})$ island of basement located in the central part of the tufa and flowed along the northern and southern palaeogullies. Downstream the water streams rejoined again forming the frontal Peña del Manto cascade located at Nogales section (Fig. 11C).

4) The fourth stage (SU-4) is recorded as a clastic input event dominated by angular quartzite-clast conglomerates that aborted carbonate deposition (Fig 11D).

5) During the fifth stage (SU-5 and SU-6) carbonate deposition was restricted to the eastern part of Peña del Manto and led to the growth of a small cascade flowing towards the southwest (SU-5). Afterwards, the frontal main cascade of SU-6 developed (Figs. 8B and 11E).

6) SU-7 marked the last deposition episode in the Peña del Manto (Fig. 11F). After the demise of tufa, conglomerates were deposited on the higher plane of the tufa forming SU-7.

Table 3

Slope, dimensions and facies proportions for the main sedimentary environments interpreted.

\begin{tabular}{|c|c|c|c|c|}
\hline & & \multicolumn{3}{|c|}{ Sedimentary environments } \\
\hline & & Cascades & Gentle-slope vegetated areas & Streams and ponds \\
\hline \multirow[t]{3}{*}{ Slope } & Min & 20 & 8 & 1 \\
\hline & Med & 50 & 10 & 3 \\
\hline & Max & 85 & 20 & 5 \\
\hline \multirow[t]{3}{*}{ Size } & $\%$ Area & 22.5 & 20.6 & 56.8 \\
\hline & Width (m) & 120 & 110 & $50-150$ \\
\hline & Length $(\mathrm{m})$ & 50 & 50 & 150 \\
\hline \multirow[t]{7}{*}{$\%$ Facies } & Phytoherm limestones of bryophytes & 90 & 5 & 2 \\
\hline & Phytoherm limestones of stems & 2 & 38 & 17 \\
\hline & Phytoclastic limestones & 2 & 15 & 1 \\
\hline & Bioclastic limestones & 1 & 0 & 45 \\
\hline & Oncolitic limestones & 4 & 31 & 30 \\
\hline & Carbonate breccias & 1 & 8 & 0 \\
\hline & Mudstones, Sandstones and conglomerates & 0 & 3 & 5 \\
\hline
\end{tabular}


(A)

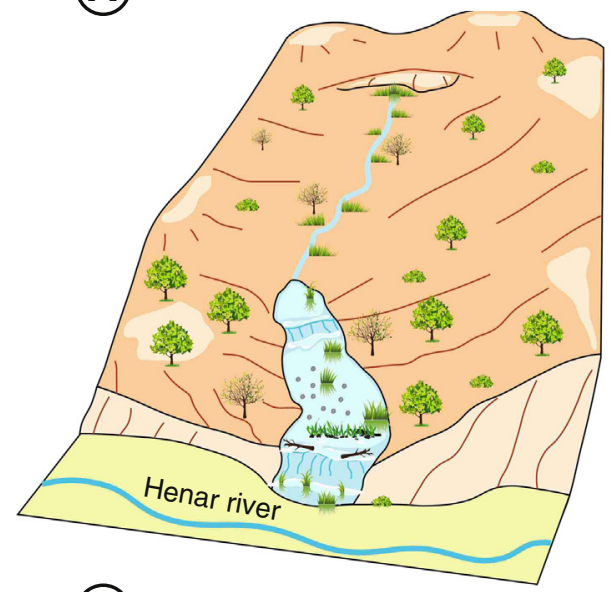

(C)

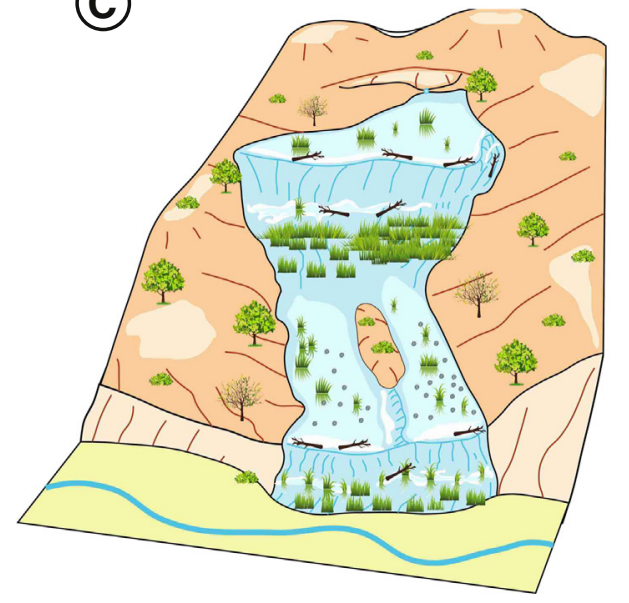

(E)

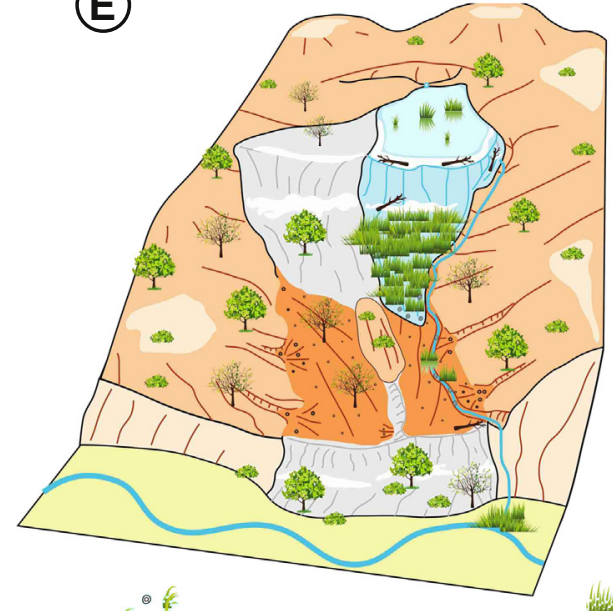

Streams and ponds

Cascades
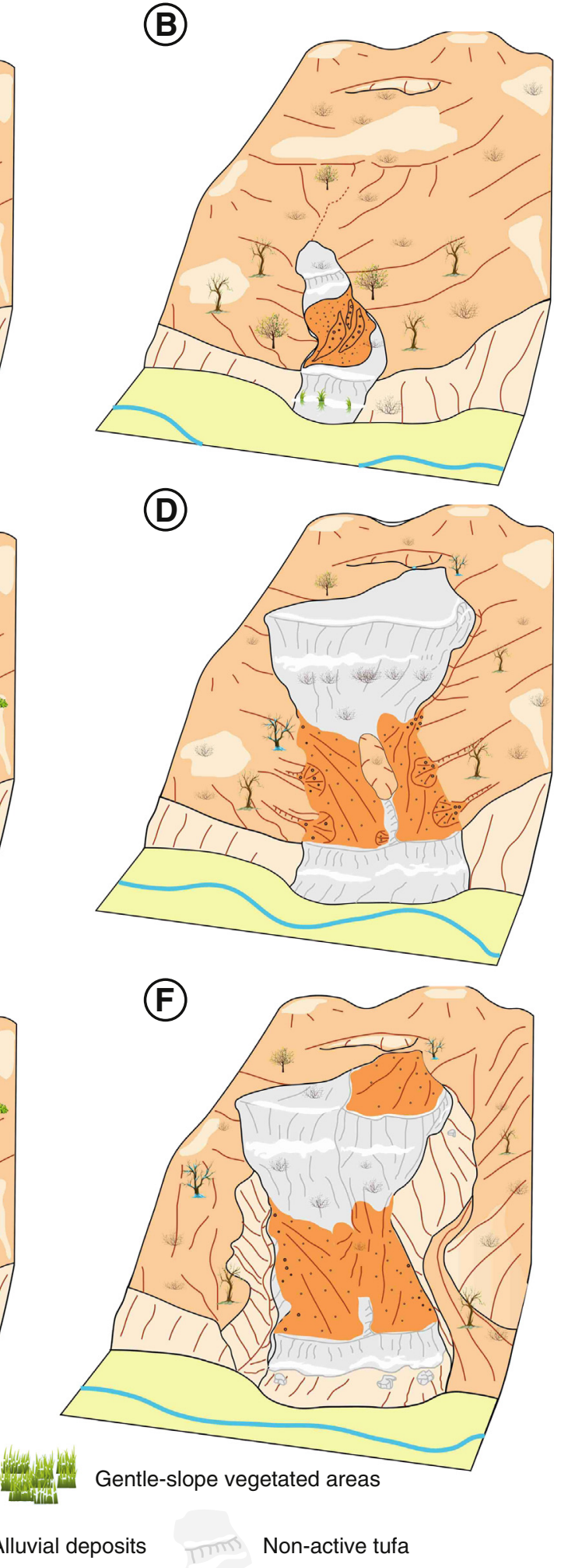

Fig. 11. Evolutive model of the Peña del Manto showing the stages with tufa growth and clastic input. Deposition of SU-1 (A); SU-2 (B); SU-3 (C); SU-4; SU-5 and SU6 (E); and SU-7 and gully incision (F).

After this moment till present day, north and south gullies incised following the contact between tufa carbonates and the terrigenous Paleogene basement (Fig. 11F). Two archaeological sites of the Magdalenian stage were found in two rock shelters located in the south gully (Alexandre site, 15,370 \pm 110 years old BP, located between the $\mathrm{S}$ and $\mathrm{F}$ sections) and in the western-most outcrops of the Peña del Manto (Vergara site, 14,000 years old BP, located around Nogales section) (Utrilla and Blasco, 2000). This suggests that at that moment the tufa was not active and the gullies were already incised.

Although tufa growth ceased in the Peña del Manto system, several springs are nowadays active in the San Roquillo and Deza springs. 


\subsection{The role of climate in the Peña del Manto tufa}

A number of factors can control carbonate precipitation in tufa systems. Alternation of tufa growth and siliciclastic input stages in the Peña del Manto tufa system could be related to climatic changes, which might have affected water table levels, spring flow discharge, ambient temperatures, vegetation cover development and soil $\mathrm{CO}_{2}$ production. Lack of radiometric ages in Peña del Manto does not allow dating the carbonate units recording tufa growth, nor correlate them with glacial and interglacial stages recognized in the Pleistocene. Nevertheless a comparison can be established between the evolution of the Peña del Manto tufa and nearby tufa deposits in Iberian ranges such as the río Piedra and río Mesa systems (Zaragoza) and the Añamaza system (Soria), which most probably developed under similar climatic conditions. These above-mentioned tufas developed mainly during odd isotopic stages (Vázquez-Urbez, 2008; Arenas et al., 2010; Sancho et al., 2010), as reported for other tufas in Europe and especially in the Mediterranean region (Hennig et al., 1983; Durán, 1989; Frank et al., 2000; Domínguez-Villar et al., 2011) Abundance of water and warm temperatures during interglacial episodes, together with forest development and the consequent soil $\mathrm{CO}_{2}$ production, favoured deposition of tufas. In contrast, the tufa interruptions by siliciclastic deposits (SU-2; SU-4; SU-7) could be related to periods with cold temperatures, higher frequency of extreme events and lowering of the groundwater table, which could have favoured the drying out of springs, thus aborting tufa deposition. Tufa growth was interrupted during glacial periods (Horvatinčić et al., 2000; Antoine and Limondin-Lozouet, 2004; Ordónez et al., 2005; Ibarra et al., 2015), although in Iberian ranges it has been reported during glacial stages (Durán, 1989; Peña et al., 2000; Valero-Garcés et al., 2008; Sancho et al., 2010).

Human impact, especially agricultural activity (González Amuchastegui and Serrano Cañadas, 2013; González-Amuchastegui and Serrano, 2015) and/or active tectonics (Martini and Capezzuoli, 2014) can also produce interruptions in tufa growth. Even so, the Peña del Manto demise was previous to the development of agriculture (Utrilla and Blasco, 2000), and there is no evidence of Quaternary tectonic uplift or deformation in the study area.

\section{Conclusions}

1. - Application of digital outcrop modelling techniques, electric resistivity tomography profiles and facies modelling provides a powerful tool for investigating tufas.

2. - In the Peña del Manto seven sedimentary units have been recognized (SU-1, to SU-7). SU-1, 3, 5 and 6 are made up of tufa deposits and SU-2, 4 and 7 of siliciclastic deposits (muds, sandstones and quartzite clast conglomerates).

3. - This tufa is made up of: 1) Steeply dipping strata dominated by phytoherm limestones of bryophytes (SSLbr) interpreted as cascades. 2) Gently dipping strata dominated by phytoherm limestones of stems (GSLst), interpreted as vegetated areas at the toe of cascades. 3) Horizontal strata dominated by bioclastic and oncoid limestones (HSLbLo) interpreted as streams with areas of slow-flowing waters and small ponds.

4. - Facies modelling of the Peña del Manto tufa contributes to an excellent 3-D visualization of facies distribution and to quantification of geological information that can help to improve classical facies sketches and models.

5. - The facies model shows that phytoherm limestones of bryophytes are predominant (43\%) of the volume of the Peña del Manto tufa. Bioclastic limestones represent $20 \%$, phytoherm limestones of stem $12 \%$, and oncolitic limestones about $8 \%$ of total rock volume. Clastics, about $15 \%$, are dominated by conglomerates.

6. - Alternation of tufa growth stages with siliciclastic input stages could be the result of climatic changes which occurred during the Mid-Late Pleistocene.

\section{Acknowledgements}

This study was funded by research projects 18.KA4A-463 A.C.01 of the University of Salamanca and CGL2014-54818-P of the Ministerio de Economía y Competitividad (MINECO). We also thank Schlumberger for providing an Academic licence for Petrel to the University of Salamanca. The authors are very grateful to the editor and reviewers (C. Arenas and an anonymous reviewer) for their comments that have notably improved the manuscript.

\section{References}

Adams, E.W., Schroder, S., Grotzinger, J.P., McCormick, D.S., 2004. Digital reconstruction and stratigraphic evolution of a microbial-dominated isolated carbonate platform (terminal Proterozoic, Nama Group, Namibia). Journal of Sedimentary Research 74, 479-497.

Amour, F., Mutti, M., Christ, N., Immenhauser, A., Agar, S.M., Benson, G.S., Tomas, S., Always, R., Kabiri, L., 2012. Capturing and modelling metre-scale spatial facies heterogeneity in a Jurassic ramp setting (Central High Atlas, Morocco). Sedimentology 59, 1158-1189.

Amour, F., Mutti, M., Christ, N., Immenhauser, A., Benson, G.S., Agar, S.M., Tomas, S., Kabiri, L., 2013. Outcrop analog for an oolitic carbonate ramp reservoir: a scale-dependent geologic modeling approach based on stratigraphic hierarchy. American Association of Petroleum Geologists 97, 845-871.

Andrews, J.E., Pedley, M., Dennis, P.F., 2000. Palaeoenvironmental records in Holocene Spanish tufas: a stable isotope approach in search of reliable climatic archives. Sedimentology 47 (5), 961-978.

Antoine, P., Limondin-Lozouet, N., 2004. Identification of MIS 11 interglacial tufa deposit in the Somme valley (France): new results from the Saint-Acheul fluvial sequence. Quaternaire 15 (1-2), 41-52.

Arenas, C., Sancho, C., Vázquez-Urbez, M., Pardo, G., Hellstrom, J., Ortíz, J.E., de Torres, T., Osácar, M.C., Auqué, L., 2010. Las tobas cuaternarias del río Añamaza (Provincia de Soria, Cordillera Ibérica): aproximación cronológica. Geogaceta 49, 51-54

Arenas, C., Vázquez-Urbez, M., Pardo, G., Sancho, C., 2014. Sedimentology and depositional architecture of tufas deposited in stepped fluvial systems of changing slope: lessons from the Quaternary Añamaza valley (Iberian Range, Spain). Sedimentology 61 (1), 133-171.

Arenas-Abad, C., Vázquez-Urbez, M., Pardo-Tirapu, G., Sancho-Marcén, C., 2010. Chapter 3 Fluvial and Associated Carbonate Deposits. In: Alonso-Zarza, A.M., Tanner, L.H. (Eds.), Carbonates in Continental Settings: Facies, Environments, and ProcessesDevelopments in Sedimentology. Elsevier, pp. 133-175.

Auqué, L., Arenas, C., Osácar, C., Pardo, G., Sancho, C., Vázquez-Urbez, M., 2014. Current tufa sedimentation in a changing-slope valley: the River Añamaza (Iberian Range, NE Spain). Sedimentary Geology 303 (0), 26-48.

Bellian, J.A., Kerans, C., Jenette, D.C., 2005. Digital outcrop models: applications of terrestrial scanning lidar technology in stratigraphic modeling. Journal of Sedimentary Research 75, 166-176.

Brasier, A.T., Andrews, J.E., Kendall, A.C., 2011. Diagenesis or dire genesis? The origin of columnar spar in tufa stromatolites of central Greece and the role of chironomid larvae. Sedimentology 58 (5), 1283-1302.

Cabello, P., Falivene, O., López-Blanco, M., Howell, J.A., Arbués, P., Ramos, E., 2011. An outcrop-based comparison of facies modelling strategies in fan-delta reservoir analogues from the Eocene Sant Llorenç Del Munt fan-delta (NE Spain). Petroleum Geoscience 17 (1), 65-90.

Camuera, J., Alonso-Zarza, A.M., Rodríguez-Berriguete, Á., Meléndez, A., 2015. Variations of fluvial tufa sub-environments in a tectonically active basin, Pleistocene Teruel Basin, NE Spain. Sedimentary Geology 330, 47-58.

Carthew, K.D., Taylor, M.P., Drysdale, R.N., 2003. Are current models of tufa sedimentary environments applicable to tropical systems? A case study from the Gregory River. Sedimentary Geology 162 (3-4), 199-218.

Das, S., Mohanti, M., 2005. Sedimentology of Holocene tufa carbonates in Orissa state, India. Carbonates and Evaporites 20 (1), 8-33.

De Filippis, L., Anzalone, E., Billi, A., Faccenna, C., Poncia, P.P., Sella, P., 2013. The origin and growth of a recently-active fissure ridge travertine over a seismic fault, Tivoli, Italy. Geomorphology 195, 13-26.

Domínguez-Villar, D., Vázquez-Navarro, J.A., Cheng, H., Edwards, R.L., 2011. Freshwater tufa record from Spain supports evidence for the past interglacial being wetter than the Holocene in the Mediterranean region. Global and Planetary Change 77 (3-4), 129-141.

Drysdale, R.N., Gillienson, D., 1997. Micro-erosion meter measurements of travertine deposition rates: a case study from Louie Creek, northwest Queensland, Australia. Earth Surface Processes and Landforms 22, 1037-1051.

Drysdale, R., Head, J., 1994. Geomorphology, stratigraphy and C-14 chronology of ancient tufas at Louie-Creek, northwest Queensland, Australia. Géographie Physique et Quaternaire 48 (3), 285-295.

Drysdale, R.N., Carthew, K.D., Taylor, M.P., 2003. Larval caddis-fly nets and retreats: a unique biosedimentary paleocurrent indicator for fossil tufa deposits. Sedimentary Geology 161 (3-4), 207-215.

Durán, J., 1989. Geocronología de los depósitos asociados al karst en España. In: Durán, J., Martínez, J. (Eds.), El karst en España. Monografía Sociedad Española de Geomorfología. Sociedad Española de Geomorfología, Madrid, Spain, pp. 243-256.

Fabuel-Pérez, I., Hodgetts, D., Redfern, J., 2010. Integration of digital outcrop models (DOMs) and high resolution sedimentology - workflow and implications for 
geological modelling: Oukaimeden Sandstone Formation, High Atlas (Morocco). Petroleum Geoscience 16 (2), 133-154.

Falivene, O., Cabrera, L., Muñoz, J.A., Arbués, P., Fernández, O., Sáez, A., 2007. Statistical grid-based facies reconstruction and modelling for sedimentary bodies. Alluvialpalustrine and turbiditic examples. Geologica Acta 5 (3), 199-230.

Ford, T.D., Pedley, H.M., 1996. A review of tufa and travertine deposits of the world. EarthScience Reviews 41, 117-175.

Frank, N., Braum, M., Hambach, U., Mangini, A., Wagner, G., 2000. Warm period growth of travertine during the last interglaciation in southern Germany. Quaternary Research 54 (1), 38-48.

Garnett, E.R., Andrews, J.E., Preece, R.C., Dennis, P.F., 2004. Climatic change recorded by stable isotopes and trace elements in a British Holocene tufa. Journal of Quaternary Science 19 (3), 251-262.

González Amuchastegui, M.J., Serrano Cañadas, E., 2013. Tufa buildups and landscape evolution: chronology and morphogenetic phases in the high Ebro basin (Burgos province). Cuaternario y Geomorfologia 27 (1-2), 9-32.

González-Amuchastegui, M.J., Serrano, E., 2015. Tufa buildups, landscape evolution and human impact during the Holocene in the Upper Ebro Basin. Quaternary International 54-64.

Hennig, G., Grün, R., Brunnacker, K., 1983. Speleothems, travertines, and paleoclimates. Quaternary Research 20 (1), 1-29.

Horvatinčić, N., Čalić, R., Geyh, M.A., 2000. Interglacial growth of tufa in Croatia. Quaternary Research 53 (2), 185-195.

Huerta, P., 2007. El Paleógeno de la cuenca de Almazán. Relleno de una cuenca piggyback. Ph. D. Thesis. Universidad de Salamanca, Salamanca (340 pp.).

Huerta, P., Armenteros, I., Recio, C., Blanco, J.A., 2010. Palaeogroundwater evolution in playa-lake environments. Palaeogeography Palaeoclimatology Palaeoecology 286 (3-4), 135-148.

Huerta, P., Armenteros, I., Silva, P.G. 2011. Large-scale architecture in non-marine basins: the response to the interplay between accommodation space and sediment supply. Sedimentology 58 (7), 1716-1736.

Ibarra, Y., Corsetti, F.A., Feakins, S.J., Rhodes, E.J., Kirby, M.E., 2015. Fluvial tufa evidence of Late Pleistocene wet intervals from Santa Barbara, California, U.S.A. Palaeogeography Palaeoclimatology Palaeoecology 422, 36-45.

Jennette, D., Bellian, J., 2003. 3-D Digital Characterization and Visualization of the Solitary Channel Complex, Tabernas Basin. Southern Spain AAPG International Conference, Barcelona, Spain.

Kenter, J.A.M., Harris, P.M., Merino-Tomé, O., Verwer, K., Pierre, A., 2008. Outcrop Analogs: Adding Value to Reservoir Characterization and Modeling. Outcrops Revitalized: Tools, Techniques and Applications. Society for Sedimentary Geology (SEMP), Kilkee, County Clare, Western Ireland, p. 38.

Lorah, M.M., Herman, J.S., 1988. The chemical evolution of a travertine-depositing stream: geochemical processes and mass transfer reactions. Water Resources Research 24 (9), 1541-1552.

Martini, I., Capezzuoli, E., 2014. Interdigitated fluvial clastic deposits and calcareous tufa testifying an uplift of the catchment area: an example from the Pianizzoli area (southern Tuscany, Italy). Sedimentary Geology 299 (0), 60-73.

Martinius, A.W., Naess, A., 2005. Uncertainty analysis of fluvial outcrop data for stochastic reservoir modelling. Petroleum Geoscience 11 (3), 203-214.

Matsuoka, J., Kano, A., Oba, T., Watanabe, T., Sakai, S., Seto, K., 2001. Seasonal variations of stable isotopic composition recorded in a laminated tufa, SW Japan. Earth and Planetary Science Letters 192, 231-244.

Merino-Tomé, Ó., Porta, G.D., Kenter, J.A.M., Verwer, K., Harris, P., Adams, E.W., Playton, T.E.D., Corrochano, D., 2012. Sequence development in an isolated carbonate platform
(Lower Jurassic, Djebel Bou Dahar, High Atlas, Morocco): influence of tectonics, eustacy and carbonate production. Sedimentology 59 (1), 118-155.

Ordónez, S., González Martín, J.A., García del Cura, M.A., Pedley, H.M., 2005. Temperate and semi-arid tufas in the Pleistocene to recent fluvial barrage system in the Mediterranean area: the Ruidera Lakes Natural Park (Central Spain). Geomorphology 69 (14), 332-350.

Öğretmen, Z., Şeren, A., 2014. Investigating fracture-cracked systems with geophysical methods in Bayburt Kiratli travertine. Journal of Geophysics and Engineering 11 (6).

Pedley, M., 1990. Classification and environmental models of cool freshwater tufas. Sedimentary Geology 68, 143-154.

Pedley, M., 2009. Tufas and travertines of the Mediterranean region: a testing ground for freshwater carbonate concepts and developments. Sedimentology 56, 221-246.

Pedley, M., Hill, I., Denton, P., Brasington, J., 2000. Three-dimensional modelling of a Holocene tufa system in the Lathkill Valley, north Derbyshire, using groundpenetrating radar. Sedimentology 47 (3), 721-737.

Pellicer, X.M., Linares, R., Gutiérrez, F., Comas, X., Roqué, C., Carbonel, D., Zarroca, M. Rodríguez, J.A.P., 2014. Morpho-stratigraphic characterization of a tufa mound complex in the Spanish Pyrenees using ground penetrating radar and trenching, implications for studies in Mars. Earth and Planetary Science Letters 388 (0), 197-210.

Peña, J.L., Sancho, C., Lozano, M.V., 2000. Climatic and tectonic significance of late Pleistocene and Holocene tufa deposits in the Mijares River canyon, eastern Iberian range, northeast Spain. Earth Surface Processes and Landforms 25 (13), 1403-1417.

Pentecost, A., Viles, H., 1994. A review and reassessment of travertine classification. Géographie Physique et Quaternaire 48 (3), 305-314.

Sancho, C., Arenas, C., Pardo, G., Vázquez, M., Hellstrom, J., Ortiz, J.E., Torres, T., Rhodes, E. Osácar, M.C., Auqué, L., 2010. Ensayo cronológico de las tobas cuaternarias del río piedra (cordillera ibérica). Geogaceta 48, 31-38.

Utrilla, P., Blasco, F., 2000. Dos asentamientos magdalenienses en Deza, Soria. Boletín de Seminario de Estudios de Arte y Arqueología 66, 9-64.

Valero, L., Huerta, P., Garcés, M., Armenteros, I., Beamud, E., Gómez-Paccard, M., 2015 Linking sedimentation rates and large-scale architecture for facies prediction in non-marine basins (Paleogene, Almazán Basin, Spain). Basin Research 1-20.

Valero-Garcés, B., Moreno, A., Navas, A., Mata, P., Machín, J., Delgado-Huertas, A. González-Sampériz, P., Schwalb, A., Morellón, M., Cheng, H., 2008. The Taravilla lake and tufa deposits (Central Iberian Range, Spain) as palaeohydrological and palaeoclimatic indicators. Palaeogeography Palaeoclimatology Palaeoecology 259 (2), 136-156

Vázquez-Urbez, M., 2008. Caracterización y significado ambiental de depósitos tobáceos neógenos de la Cuenca del Ebro. Comparación con ambientes Cuaternarios. PhD Thesis. Universidad de Zaragoza, Zaragoza (476 pp.).

Vázquez-Urbez, M., Arenas, C., Pardo, G., 2012. A sedimentary facies model for stepped, fluvial tufa systems in the Iberian range (Spain): the Quaternary Piedra and Mesa valleys. Sedimentology 59 (2), 502-526.

Verwer, K., Adams, E.W., Kenter, J.A.M., 2007. Digital outcrop models: technology and applications. First Break 25 (8), 57-63.

Verwer, K., Merino-Tome, O., Kenter, J.A.M., Porta, G.D., 2009a. Evolution of a high-relief carbonate platform slope using 3D digital outcrop models: lower Jurassic Djebel Bou Dahar, High Atlas, Morocco. Journal of Sedimentary Research 79 (6), 416-439.

Verwer, K., Porta, G.D., Merino-TomÉ, O., Kenter, J.A.M., 2009b. Controls and predictability of carbonate facies architecture in a Lower Jurassic three-dimensional barrier-shoal complex (Djebel Bou Dahar, High Atlas, Morocco). Sedimentology 56 (6), 1801-1831.

Yélamos, J.G., Sanz Pérez, E., 1998. Hidrogeología regional del acuífero cretácico de los manatiales termales de Alhama de Aragón (Zaragoza y Soria). Revista de la Sociedad Geológica de España 11 (1-2), 151-167. 